\title{
Cancer Gene Therapy Using Plasmid DNA: Pharmacokinetic Study of DNA Following Injection in Mice
}

\author{
DENISE LEW, ${ }^{1}$ SUEZANNE E. PARKER, ${ }^{1}$ TERRIE LATIMER, ${ }^{1}$ ANNA M. ABAI, ${ }^{1}$ \\ ANN KUWAHARA-RUNDELL, ${ }^{1}$ SOEUN GRACE DOH,${ }^{1}$ ZHI-YONG YANG,${ }^{3}$ DRAKE LAFACE, ${ }^{2}$ \\ STANISLAW H. GROMKOWSKI, ${ }^{1}$ GARY J. NABEL,${ }^{3}$ MARSTON MANTHORPE, ${ }^{1}$ and JON NORMAN ${ }^{1}$
}

\begin{abstract}
The fate of plasmid DNA complexed with cationic lipids delivered intravenously in mice was evaluated at selected timepoints up to 6 months postinjection. Blood half-life and tissue distribution of plasmid DNA and potential expression in tissues were examined. Southern blot analyses of blood indicated that intact plasmid DNA was rapidly degraded, with a half-life of less than $5 \mathrm{~min}$ for intact plasmid, and was no longer detectable at $1 \mathrm{hr}$ postinjection. Southern analyses of tissue demonstrated that intact DNA was differentially retained in the lung, spleen, liver, heart, kidney, marrow, and muscle up to $24 \mathrm{hr}$ postinjection. After 7 days, no intact plasmid DNA was detectable by Southern blot analysis; however, the plasmid was detectable by the polymerase cliain reaction (PCR) in all tissues examined at 7 and 28 days postinjection. At 6 months postinjection, femtograin levels of plasmid were detected only in muscle. Immunohistochemical analyses did not detect encoded protein in the tissues harboring residual plasınid at 1 or 7 days postinjection.
\end{abstract}

\section{OVERVIEW SUMMARY}

The present study evaluates the pharmacokinetic half-life and tissue distribution of plasmid DNA following intravenous injection in mice. This study extends the time frame of previous in vivo analyses to 6 months following i.v. injection. Injected mice exhibit no expression of the encoded gene as assayed by immunofluorescence. This represents the first systematic in vivo pharmacokinetic study of intravenously injected DNA complexed with cationic lipids, and is relevant to many gene therapy protocols utilizing direct injection of plasmid DNA plus lipids. The results provide a preliminary basis for the safe initiation of cancer immunotherapy clinical trials in which plasimid DNA is directly injected into tumors.

\section{INTRODUCTION}

D IRECT INTRATUMORAL INJECTION OF PLASMID DNA encoding foreign surface antigens or cytokines is a promising new approach for the treatment of cancer (Nabel et al., 1992b, 1993; Vile and Hart, 1993). While a majority of malignancies arise in immunocompetent hosts, tumors escape host defenses. One theory by which tumor cells may evade immune surveillance is by altering their ability to express the major histocompatibility complex (MHC) class I molecules on their cell surfaces, thereby rendering themselves less visible to the immune system. Freshly isolated cells from naturally occurring tumors frequently lack or have decreased expression of MHC class I antigens (Schmidt et al., 1981; Isakov et al., 1983; Lampson et al., 1983; Funa et al., 1986). Studies have shown that direct

\footnotetext{
${ }^{1}$ Vical, Inc., San Diego, CA 92121.

${ }^{2}$ The Scripps Research Institute, La Jolla, CA 92037.

${ }^{3}$ Howard Hughes Medical Institute, Departments of Internal Medicine and Biological Chemistry, University of Michigan Medical Center, Ann Arbor, MI 48109.
} 
gene transfer of MHC class I molecules into tumors may facilitate recognition of tumors by the immune system (Nabel $e t$ al., 1992b; Nabel et al., 1993).

Although an ex vivo approach of transfecting cells from individual patients for gene therapy has been successful, there are some limitations to the technique. These include the need to culture cells in vitro from each patient to avoid allogeneic tissue rejection, the tendency of cells to undergo phenotypic alteration in culture, the possibility of outgrowth of aberrant transformed cells, and the requirement for expertise to prepare cultured cells prior to reintroduction. Additionally, many gene therapy protocols require transduction with an integrating retroviral vector prior to reintroduction of the cells in vivo, thereby raising safety concerns.

In vivo introduction of recombinant DNA into tumors utilizing plasmid DNA expression vectors simplifies the gene transfer procedure and minimizes delays in treatment. Although tumors are the ultimate target of this gene transfer technology, the design of the current studies addresses the effects of DNA circulated inadvertantly throughout the body, which may result following direct tumor injection. The intravenous (i.v.) route of plasmid DNA injection was investigated because it provides the greatest potential for detection of systemic expression and manifestation of systemic toxicity.

Studies in mice have demonstrated the overall safety of i.v. DNA-cationic lipid injection as an in vivo gene transfer methodology (Nabel et al., 1992; Stewart et al., 1992). A previous clinical protocol utilized direct DNA injection into tumors for cancer immunotherapy trials (Nabel et al., 1992b). The introduction of the gene encoding the heavy chain of an MHC class I molecule, HLA-B7, into patients with end-stage IV melanoma appeared to be safe. It resulted in transgene expression localized to the site of injection and was associated with tumor regression in 1 of 5 patients (Nabel et al., 1993). We have expanded upon this initial finding and have entered a phase I clinical trial with a modified expression vector, pVCL-1005, encoding both the HLA-B7 heavy chain gene and the $\beta 2$-microglobulin $\left(\beta_{2} \mathrm{~m}\right)$ light chain gene. This plasmid contains a sequence encoding an internal ribosome entry site (IRES) between the HLA-B7 and $\beta_{2} m$ cDNAs to coexpress them from the same promoter (Parks et al., 1986; Jang et al., 1988, 1989; Ghattas et al., 1991). This differs from the plasmid used in the first clinical trial (Nabel et al., 1993) in that the addition of an IRES and the gene encoding $\beta_{2} \mathrm{~m}$ improves the expression level of the complete MHC class I molecule, containing both heavy and light polypeptide chains. In this preclinical study, the tissue distribution and half-life of pVCL-1005 plasmid DNA was analyzed over an extended period of time following i.v. injection in mice as VCL-1005, plasmid complexed with cationic lipids.

We found that the injected plasmid DNA persisted for at least 6 months postinjection following i.v. administration. Moreover, by immunohistochemical analysis, there was no detectable protein expression in those tissues that retained the greatest amount of plasmid. These results provided a basis for the expansion of human clinical trials using direct plasmid DNA injection.

\section{MATERIALS AND METHODS}

\section{Plasmids}

Supercoiled plasmid DNA was prepared by the method of Horn et al. (1995). Plasmid pCMVintLux (Manthorpe et al.,
1993) contains the human cytomegalovirus immediate early gene promoter (Thomsen et al., 1984; Boshart et al., 1985; Ghazal et al., 1987) and intron A (Chapman et al., 1991) at the $5^{\prime}$ end of a cDNA encoding the gene for firefly luciferase (De Wet et al., 1987). Additionally, pCMVintLux possesses the SV40 small $\mathrm{T}$ intron and polyadenylation processing signal at the $3^{\prime}$ end of the cDNA for luciferase (Fig. 1A).

Plasmid pVCL-1005 contains the Rous sarcoma virus long terminal repeat (RSV-LTR) (Gorman et al., 1983) promoter/ enhancer that drives transcription of both the MHC class I human leukocyte antigen B7 gene (HLA-B7) and the chimpanzee $\beta_{2} \mathrm{~m}$ gene (Fig. 1B). The HLA-B7 gene was originally derived from the plasmid pLJ-HLAB7, a gift from Dr. Alan Korman (Institut Pasteur, Paris). The cDNA for HLA-B7 heavy chain was originally cloned from a human B-cell library. The cDNA encoding chimpanzee $\beta_{2} \mathrm{~m}$ was included to allow synthesis and expression of the complete major histocompatibility complex on the cell surface (Zamoyska and Parnes, 1988; Williams et al., 1989). The clone encoding $\beta_{2} m$ was a gift from Dr. Alejandro Madrigal, Stanford University. An internal ribosome entry site (IRES) sequence was placed between the HLA-B7 and $\beta_{2}$ m cDNAs. The IRES was used to enable coexpression of the two genes from a single promoter in eukaryotic cells (Elroy-Stein et al., 1989; Morgan et al., 1992). To facilitate purification of the plasmid, and to obviate the use of ampicillin selection during the growth of the bacteria, the gene encoding ampicillin resistance ( $\beta$-lactamase) was replaced with the gene encoding kanamycin resistance (aminoglycoside phosphotransferase) originally derived from the bacterial transposon Tn903 (Nomura et al., 1978). pVCL-1005 also possesses transcript polyadenylation and termination signals from the bovine growth hormone polyadenylation sequence (Gordon et al., 1983).

Plasmid pVCL-1004 contains the identical pBR322 backbone, kanamycin resistance gene, RSV-LTR promoter, and HLA-B7 sequences as pVCL-1005. However, it lacks the IRES and $\beta_{2} \mathrm{~m}$ sequences, and the eukaryotic transcript is terminated with the SV40 small $t$ antigen gene polyadenylation and termination sequence. Plasmid pRSV-BL contains the RSV promoter in a pBR322 backbone and has been previously described (Manthorpe et al., 1993). Plasmid pRSV-lac Z encodes the gene for $\beta$-galactosidase $(\beta-\mathrm{Gal})$ under control of the RSV promoter in a pBR322 backbone and has been previously described (Norton and Coffin, 1985).

\section{In vitro transfection and immunofluorescent staining}

The plasmids described above were transfected into L293 human embryonal kidney cells ( $\beta_{2} \mathrm{~m}$ positive/HLA-B7 positive) and UM-449 human melanoma cells $\left(\beta_{2} \mathrm{~m}\right.$ negative/ HLA-B7 negative) using cationic lipid-based delivery. Cationic lipid reagents contain a net positive charge, and can bind to negatively charged molecules of DNA. Such reagents have been shown to facilitate transfection of plasmid DNA into cells cultured in vitro (Felgner et al., 1987; Wang and Huang, 1989) and were used successfully in vivo in the clinical protocol for a previous cancer immunotherapy trial (Nabel et al., 1992b). The transfection reagent used in the above clinical protocol, pVCL1004 complexed with DC-Cholesterol:DOPE at a cationic lipidto-DNA molar ratio of 3.0, was used for reference in this in vitro experiment. The cationic lipid DMRIE (1,2-dimyristoyl- 
oxypropyl-3-dimethyl ammonium bromide; Felgner et al., 1994) and the neutral lipid DOPE (dioleoyl phosphatidylethanolamine; Felgner, 1990) were formulated into liposomes at an equimolar ratio (1:1). With either plasmid, $2 \times 10^{5}$ cells in six-well plates were transfected with $20 \mu \mathrm{g}$ of DNA, complexed with the appropriate lipid, in $2 \mathrm{ml}$ of OptiMEM (GIBCO/BRL, Gaithersburg, MD) at $37^{\circ} \mathrm{C}$. Four hours later, an additional $2 \mathrm{ml}$ of OptiMEM/20\% fetal bovine serum (FBS) was added to the cultures, and the cells continued to incubate for a total of $48 \mathrm{hr}$. Cells were then rinsed with $2-3 \mathrm{ml}$ of phosphate-buffered saline (PBS), harvested in $2 \mathrm{ml}$ of PBS containing $2 \mathrm{~m} M$ EDTA, and divided between two $12 \times 75$ mm polystyrene culture tubes (about $0.5 \times 10^{6}$ cells per tube). Cells were gently pelleted by centrifugation at $300 \times \mathrm{g}$ for 7 min at $4^{\circ} \mathrm{C}$. Supernatants were discarded and one half of each culture was incubated for $1 \mathrm{hr}$ on ice with either $100 \mu \mathrm{l}$ antiHLA-B7 monoclonal antibody (culture supernatant from hybridoma BB7.1, ATCC \#HB56) for specific staining, or $100 \mu \mathrm{l}$ of PBS, 5\% fetal bovine serum (FBS) for nonspecific staining. All incubations and washes were done with chilled reagents and buffers containing $0.1 \% \mathrm{NaN}_{3}$. Cells were washed with $4 \mathrm{ml}$ of PBS and incubated in the dark with R-phycoerythrin-labeled sheep anti-mouse $\mathrm{IgG}, \mathrm{F}\left(\mathrm{ab}^{\prime}\right)_{2}$ fragment for $0.5 \mathrm{hr}$ on ice. Cells were washed with PBS, resuspended in $0.2-0.4 \mathrm{ml}$ of $\mathrm{PBS} / 1 \%$ formaldehyde, and stored in the dark at $4^{\circ} \mathrm{C}$ until analyzed by flow cytometry.

Flow cytometric analysis was performed with a FACScan/ LYSIS II system (Becton-Dickinson), using a 488-nm argon laser for excitation and the FL2 channel for detection at $585 \mathrm{~nm}$. For each sample, 10,000 cells were counted, in triplicate. Data acquired from the triplicate determinations were presented in combined single-parameter fluorescence histograms, comparing for each sample the negative control distribution (nonspecifically stained cells) and test distribution (specifically stained cells). Cells of interest were identified by light scatter; data analysis gates were placed during analysis. In addition, the frequency of positive cells in each culture was determined by threshold analysis, setting the cut-off value for false positivity at $3 \%$. This method may underestimate the positive population when there is an overlap between positive and negative distributions, but allows a semiquantitative evaluation of pVCL-1005 relative to pVCL-1004. Flow cytometry analysis was performed by Cytometry Sorting Specialities (San Diego, CA).

\section{Preparation of VCL-1005 for in vivo studies}

VCL-1005 is defined as the formulation consisting of a plasmid DNA, pVCL-1005, complexed with the cationic lipid DMRIE/DOPE at a DNA/lipid mass ratio of 5:1. VCL-1005 was prepared for administration by diluting the plasmid DNA pVCL-1005 with lactated Ringer's solution to a concentration of $1.0 \mathrm{mg} / \mathrm{ml}$. The lyophilized lipid DMRIE/DOPE was reconstituted in a single vial with lactated Ringer's solution to a concentration of $0.96 \mathrm{mg} / \mathrm{ml}$ DMRIE and $1.12 \mathrm{mg} / \mathrm{ml}$ DOPE and diluted 1:4 with lactated Ringer's to give a final concentration of $0.192 \mathrm{mg} / \mathrm{ml}$ of DMRIE and $0.224 \mathrm{mg} / \mathrm{ml}$ DOPE. An equal volume of plasmid DNA at $1.0 \mathrm{mg} / \mathrm{ml}$ was mixed by gentle vortexing with diluted DMRIE/DOPE to form VCL1005. This complex was used immediately for i.v. injection into mice. CMVintLux was prepared for injections in the same manner as VCL-1005.

\section{Intravenous administration of VCL-1005}

Plasmid DNA-lipid complexes were prepared as described and administered to ICR mice (6 weeks old, Harlan Sprague Dawley, San Diego, CA) as a single i.v. dose of $100 \mu \mathrm{l}(50 \mu \mathrm{g}$ of plasmid DNA) via the tail vein. Three female mice per timepoint were used for blood time course studies, and two males and two females per timepoint for tissue time course studies.

\section{DNA isolation and analysis}

Mice were sacrificed at the indicated times postinjection and exsanguinated by cardiac puncture. Blood was immediately mixed with EDTA to a final concentration of $100 \mathrm{mM}$ in microfuge tubes and frozen in liquid nitrogen. The following tissues were then taken for subsequent analysis: bone marrow (femur), brain, heart, kidney, liver, lung, large intestine, small intestine, ovary/testis, spleen, and quadriceps muscle. Each tissue was placed in a microfuge tube and immediately frozen in liquid nitrogen. Tissues and blood were stored at $-80^{\circ} \mathrm{C}$ until DNA extraction.

DNA was isolated from blood or tissues by overnight incubation at $65^{\circ} \mathrm{C}$ with $0.5 \mathrm{ml} /$ tube of $0.5 \mathrm{mg} / \mathrm{ml}$ proteinase $\mathrm{K}$ (Boehringer-Mannheim, Indianapolis, $\mathrm{IN}$ ) in $50 \mathrm{mM}$ Tris- $\mathrm{HCl}$ pH 8.0, $100 \mathrm{~m} M$ EDTA, $100 \mathrm{~m} M \mathrm{NaCl}, 1 \%$ SDS. Each mixture was subsequently extracted two to four times with equal volumes of buffered phenol, and then extracted with chloroform one to two times. DNA was precipitated at room temperature with 2 volumes of ethanol, pelleted at $12,000 \times \mathrm{g}$ in a microfuge for $10 \mathrm{~min}$, rinsed in $70 \%$ ethanol, and dried at room temperature in a laminar flow hood. The DNA pellets were resuspended in $100 \mu \mathrm{l}$ water with $0.1 \mathrm{mg} / \mathrm{ml}$ RNase A (Sigma, St. Louis, MO) and incubated at $37^{\circ} \mathrm{C}$ for $30 \mathrm{~min}$. To remove digested RNA, DNA was again precipitated at room temperature with 2 volumes of ethanol, pelleted in a microfuge for 10 min, rinsed in $70 \%$ ethanol, and dried at room temperature in a laminar flow hood. The DNA pellet was rehydrated in 50-100 $\mu l$ of water. $\mathrm{OD}_{260}$ readings were taken to determine DNA concentration. A $1-\mu \mathrm{g}$ sample was run on a $0.8 \%$ agarose gel to visually confirm concentration of samples.

\section{Southern blot analysis}

Sample DNA (5-10 $\mu \mathrm{g} / \mathrm{lane})$ was separated by electrophoresis on $1 \%$ agarose in $1 \times$ TAE buffer (Ausubel et al., 1987) at $35 \mathrm{~V}$ overnight. DNA was transferred by standard Southern blot procedures to Genescreen hybridization transfer membrane (Dupont NEN, Boston, MA) using a Posiblot pressure control apparatus under conditions recommended by the manufacturer (Stratagene, La Jolla, CA). Following transfer and UV crosslinking of DNA to the filter, membranes were prehybridized for $15 \mathrm{~min}$ to $3 \mathrm{hr}$ in $1 \%$ bovine serum albumin (BSA), 7\% SDS, $0.5 \mathrm{M} \mathrm{NaHPO}_{4} \mathrm{pH} 7.2,1 \mathrm{mM}$ EDTA at $65^{\circ} \mathrm{C}$, and were then hybridized to the probe at $65^{\circ} \mathrm{C}$ overnight. The probe to pCMVintLux was a random-primed ${ }^{32} \mathrm{P}$-labeled 1,289-bp Xba I-Eco $\mathrm{RV}$ fragment of plasmid pRSV-luciferase. The probe to the HLA-B 7 portion of VCL-1005 was a random-primed ${ }^{32} \mathrm{P}-\mathrm{la}$ beled 1,058-bp $B g l$ II digest fragment. Blots were washed in $2 \times \mathrm{SSC}, 0.1 \% \mathrm{SDS}$ at room temperature for $10 \mathrm{~min}$, and then in $0.5 \% \mathrm{BSA}, 1 \% \mathrm{SDS}, 40 \mathrm{mM} \mathrm{NaHPO}_{4} \mathrm{pH} 7.2,1 \mathrm{~m} M$ EDTA 
at $65^{\circ} \mathrm{C}$ for $1 \mathrm{hr}$ with multiple changes of buffer (Ausubel et al., 1987).

\section{PCR analysis}

Two sets of primers specific to plasmid sequences were made to amplify either a junction between the $3^{\prime}$ end of the RSV promoter and $5^{\prime}$ end of HLA-B7, or within the kanamycin resistance gene. HLA-1s sense and HLA-3a antisense primers produced an amplicon 491 bp in size. Kan 1s sense and Kan 3a antisense primers amplified a 426-bp fragment.

\section{HLA 1s sense primer \\ 5'-GCAACATGCCTTACAAG- GAG-3' \\ HLA 3a antisense primer $5^{\prime}$-TAGATCTGTGTGTTCCG- GTCC-3' \\ Kan 1s sense primer \\ Kan 3a antisense primer \\ 5'-GGCAAGATCCTGG- TATCGGT- $3^{\prime}$ \\ 5'-CGTACTCCTGATGATG- CATGG-3'}

Primers were end-labeled in a kinase reaction containing 500 pmoles of oligonucleotide, $250 \mu \mathrm{Ci}(12.5 \mu \mathrm{l})\left[\gamma^{-}{ }^{32} \mathrm{P}\right] \mathrm{ATP}$ (Dupont-NEN, $>6,000 \mathrm{Ci} / \mathrm{mmole}), 1 \times \mathrm{T} 4$ kinase buffer $(70 \mathrm{mM}$ Tris- $\mathrm{HCl}, \mathrm{pH} 7.6,10 \mathrm{mM} \mathrm{MgCl} 2,5 \mathrm{mM}$ dithiothreitol), and 10 units of T4 kinase (New England Biolabs) in a 50- $\mu$ l reaction volume. The reaction was carried out for $30 \mathrm{~min}$ at $37^{\circ} \mathrm{C}$ and stopped with $1 \mu \mathrm{l}$ of $0.5 \mathrm{mM}$ EDTA.

Hot-start PCR amplification using Ampliwax beads (PerkinElmer) was performed in a Perkin-Elmer 9600 thermocycler using the following program:

$1 \times 94^{\circ} \mathrm{C}, 3^{\prime} ; 58^{\circ} \mathrm{C}, 110^{\prime \prime} ; 75^{\circ} \mathrm{C}, 45^{\prime \prime}$

$5 \times 94^{\circ} \mathrm{C}, \mathrm{l}^{\prime} ; 58^{\circ} \mathrm{C}, 110^{\prime \prime} ; 75^{\circ} \mathrm{C}, 45^{\prime \prime}$

$25 \times 94^{\circ} \mathrm{C}, 1^{\prime} ; 58^{\circ} \mathrm{C}, 110^{\prime \prime} ; 75^{\circ} \mathrm{C}, 1^{\prime}$

$1 \times 94^{\circ} \mathrm{C}, 1^{\prime} ; 58^{\circ} \mathrm{C}, 110^{\prime \prime} ; 75^{\circ} \mathrm{C}, 6^{\prime}$

The final concentrations for all PCR components in a 100- $\mu$ l volume were as follows: $200 \mu M$ of each dNTP, 20 pmoles of each labeled primer, $1 \mu \mathrm{g}$ of extracted genomic DNA, and 2 units of Taq Polymerase (Stratagene) in 1× Taq Polymerase buffer (10 mM Tris, pH 8.3, $50 \mathrm{~m} M \mathrm{KCl}, 1.5 \mathrm{mM} \mathrm{MgCl}_{2}$, $0.01 \%$ gelatin).

PCR reactions were run on nondenaturing $5.6 \%$ polyacrylamide gels with $1 \times$ TBE running buffer. Gels were run at $80 \mathrm{~V}$ for $14 \mathrm{hr}$ or at $120 \mathrm{~V}$ for $7 \mathrm{hr}$. Twenty percent of the PCR reaction was loaded per lane with $1 \times$ stop dye. Gels were dried and exposed to Fuji RX autoradiographic film. Exposure times ranged from $30 \mathrm{~min}$ to $3 \mathrm{hr}$.

\section{Immunohistochemical analyses}

HLA-B7 expression was analyzed in ICR mouse liver, spleen, heart, lung, and kidney tissues using avidin-biotin immunoperoxidase staining at $24 \mathrm{hr}(n=4)$ and 7 days $(n=4)$ following i.v. injection of VCL-1005. Two animals injected with pRSV-BL served as negative controls. Anti-HLA-B7 monoclonal antibody (mAb) BB7.1 or $\mathrm{H}_{2} \mathrm{~K}^{\mathrm{d}} \mathrm{mAb}$ SF1-1.1 (PharMingen, San Diego, CA), were used at a concentration of $7.14 \mu \mathrm{g} / \mathrm{ml}$. Spleen, lymph nodes, and liver tissues from a
HLA-B $7 / \mathrm{h} \beta_{2}$ m double-transgenic mouse were used as positive controls and were the generous gift of Dr. Per Peterson (The Scripps Research Institute, La Jolla, CA). Samples were embedded in O.C.T. (Tissue Tek, Elkhart, IN) and frozen in liquid nitrogen. Serial sections $(6-8 \mu \mathrm{m})$ from two randomly selected areas of tissue were cut with a cryostat microtome, air-dried on glass slides at room temperature for $30 \mathrm{~min}$, fixed in acetone for $15 \mathrm{sec}$ at $-20^{\circ} \mathrm{C}$, and stored at $-70^{\circ} \mathrm{C}$. All subsequent steps were performed at room temperature. Liver tissue sections were treated with avidin/biotin blocking kit as described by the manufacturer (Zymed, South San Francisco, CA). Adjacent sections from each sample were incubated in $1 \%$ normal rabbit serum in PBS for 15 min to block nonspecific binding, and then incubated with biotinylated anti-HLA-B7 mAb or anti-H-2k ${ }^{d}$ $\mathrm{mAb}$ for $1 \mathrm{hr}$. After three 5-min washes in PBS, $4 \mu \mathrm{g} / \mathrm{ml}$ peroxidase-conjugated streptavidin (Jackson ImmunoResearch Labs, West Grove, PA) was applied for $30 \mathrm{~min}$. After another wash, the peroxidase staining was developed using an AEC chromogen kit (3-amino, 9-ethyl carbazole, Biomeda, Foster City, CA) as recommended by the manufacturer. Sections were then counterstained with Mayer's hematoxylin (Zymed), washed in tap water, and mounted with Aqua-mount (Lerner Laboratories, Pittsburgh, PA).

\section{RESULTS}

Three plasmids were chosen for this study, pCMVintLux, pVCL-1004 and pVCL-1005 (Fig. 1). The first, pCMVintLux, contains the gene encoding firefly luciferase under the control of the CMV promoter. The second, pVCL-1004, contains the HLA-B7 heavy-chain CDNA under the control of the RSV 3' LTR promoter and has been shown to express its gene product in transfected tumor cells in vivo (Nabel et al., 1993). The third, pVCL-1005, is a modified version of pVCL-1004 designed to enhance expression of the MHC class 1 antigen HLAB7. It contains two cDNAs transcribed as a single mRNA: HLA-B7 heavy chain plus chimpanzee $\beta_{2} \mathrm{~m}$ light chain, under the control of a single RSV promoter (see Materials and Methods). The peptide sequences of chimpanzee and human $\beta_{2} \mathrm{~m}$ are identical (Suggs et al., 1981). The $\beta_{2} \mathrm{~m}$ light chain is necessary for the complete MHC class I molecule to be expressed on the cell surface (Williams et al., 1989). HLA-B7 is a MHC class I molecule which, if seen as allogeneic, may stimulate tissue rejection by identifying expressing cells as foreign to a nonexpressing host. Plasmid maps of pCMVintLux, pVCL-1004 and pVCL-1005 are shown in Fig. 1.

\section{Expression in cultured cells}

Prior to in vivo analysis, HLA-B7 cell-surface expression from pVCL-1004 and pVCL-1005 was initially assessed in vitro in transfected L293 embryonal kidney cells $\left(\beta_{2} \mathrm{~m}^{+}\right)$and UM-449 melanoma cells $\left(\beta_{2} \mathrm{~m}^{-}\right)$. Expression was analyzed by flow cytometry using fluorescence-labeled secondary antibodies. The $\beta_{2} \mathrm{~m}^{+}$L293 cells express endogenous HLA-B7 on the cell surface, as demonstrated by fluorescence on cells transfected with the negative control plasmid, pRSV-LacZ (Fig. $2 A)$. However, transfection of $L 293$ cells with plasmid pVCL1004 (HLA-B7 only, Fig. 2B) or with pVCL-1005 (HLA-B7 
A

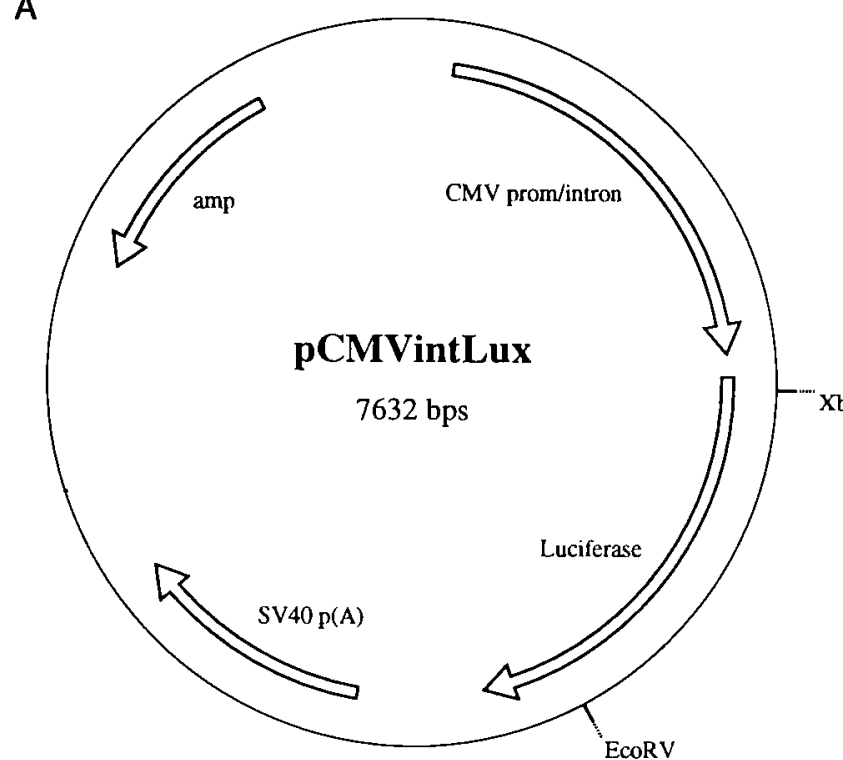

B

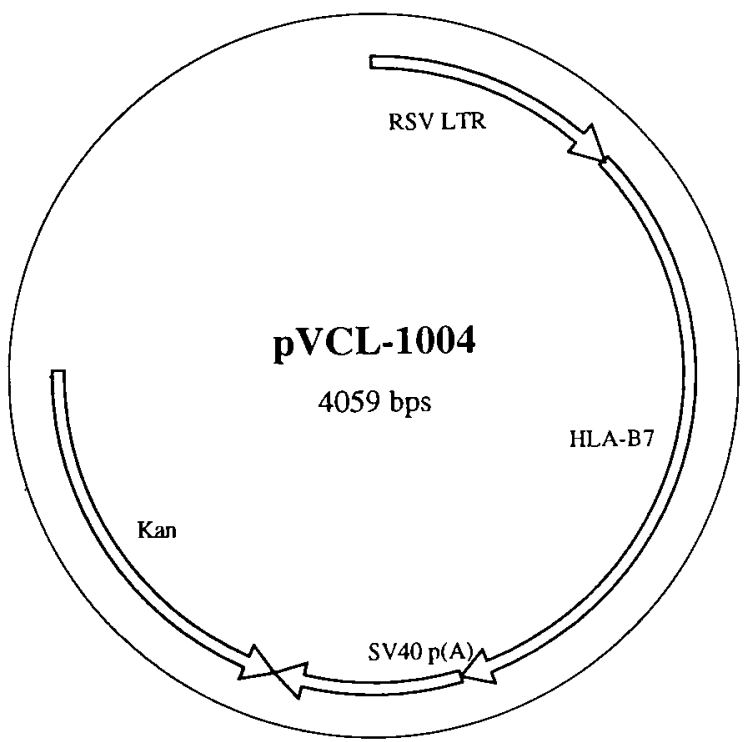

C

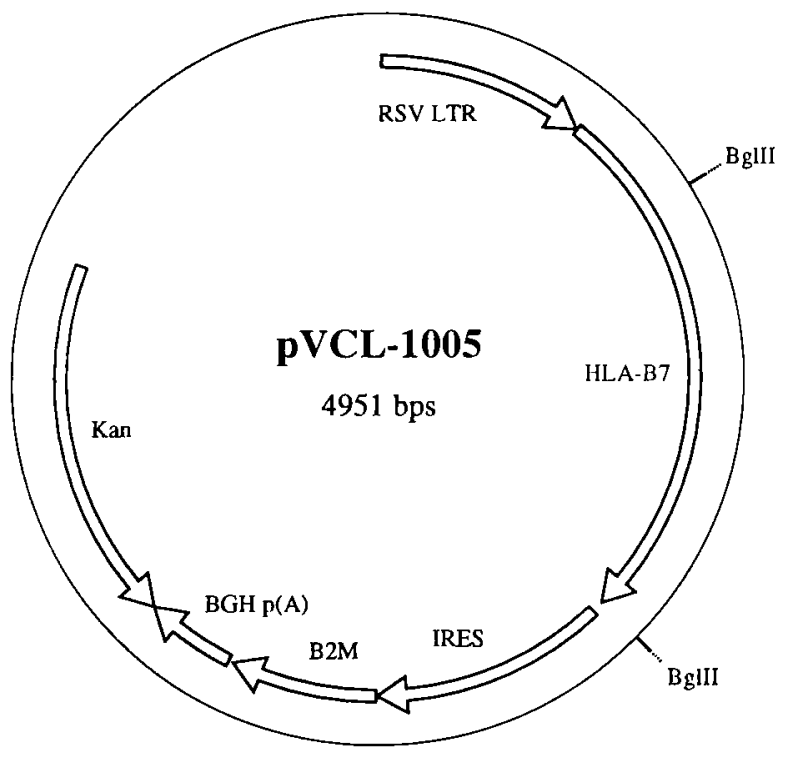

and $\beta_{2} \mathrm{~m}$, Fig. 2C) enhanced HLA-B7 expression, as indicated by the population of cells that have greater fluorescence intensity. Transfection with pVCL-1005 appeared to generate about 1.5-fold more HLA-B7 positive cells than transfection with pVCL-1004.

To test the difference between bicistronic expression of HLA-B7 heavy chain plus $\beta_{2} \mathrm{~m}$ light chain and monocistronic expression of HLA-B7, $\beta_{2} \mathrm{~m}^{-}$UM-449 melanoma cells were transfected with either pVCL-1005 or pVCL-1004. pRSVLacZ transfection served as a negative control with which cells bal appeared to have little detectable expression of HLA-B7 (Fig. 2D). Transfection with pVCL-1004 generated only low levels of HLA-B7 expression (Fig. 2E). However, transfection with pVCL-1005, containing genes encoding both HLA-B7 and $\beta_{2} \mathrm{~m}$, elicited an increase in detectable levels of HLA-B7 cellsurface expression (Fig. 2F). The antibody to HLA-B7 is specific for the complete MHC class I molecule, including both light and heavy chains. Thus, the inclusion of the $\beta_{2} \mathrm{~m}$ gene in the HLA-B7 expression vector resulted in increased HLA-B7 expression in cells which otherwise appear deficient in the expression of this protein.

\section{Pharmacokinetics of plasmid in blood}

Following the detection of efficient cell surface expression in vitro of HLA-B7 from the pVCL-1005 construct, experiments were carried out to determine the systemic distribution of plasmid DNA following i.v. tail injections in mice. An immune response, while desirable in the tumors to which the plasmid is targeted, could inadvertantly be elicited against normal tissues should the plasmid be expressed indiscriminantly throughout the body. Thus, a pharmacokinetic analysis of plasmid DNA in blood following i.v. injection was conducted using Southern blot analysis. Range-finding studies were initiated with the i.v. administration of $50 \mu \mathrm{g}$ of pCMVintLux plasmid DNA, predominantly supercoiled, complexed with DMRIE/DOPE. Total DNA was isolated from blood at $1,5,15,30$, and $60 \mathrm{~min}$ postinjection and analyzed by Southern blot. The results indicated that supercoiled plasmid was not present, and that intact linear and relaxed circular plasmid forms were detected, but rapidly diminished between 1 and 30 min postinjection (Fig. $3 \mathrm{~A})$. Over the time course analyzed, the probe hybridized to material migrating faster than intact plasmid that gave the appearance of a smear on the blot. This indicated homologous but degraded plasmid sequences migrating at molecular weights

FIG. 1. A. Plasmid map of pCMVintLux. The cytomegalovirus immediate early gene promoter/enhancer and intron $\mathrm{A}$ control the cDNA encoding firefly luciferase (Lux). B. Plasmid map of pVCL-1004. The RSV-LTR promoter drives expression of the cDNA for HLA-B7. C. Plasmid map of pVCL-1005. The RSV-LTR promoter drives expression of 2 cDNAs, HLA-B7, and $\beta_{2} \mathrm{~m}$. The two genes are separated by an internal ribosomal entry site (IRES), which permits coexpression of the two genes from a single promoter in eukaryotic cells. SV40 int $p(A)$, SV40 small $t$ intron and polyadenylation signal; bGH $p(A)$, bovine growth hormone transcription terminator and polyadenylation signal; amp, $\beta$-lactamase gene; kan, aminoglycoside phosphotransferase gene. 


\section{L293}
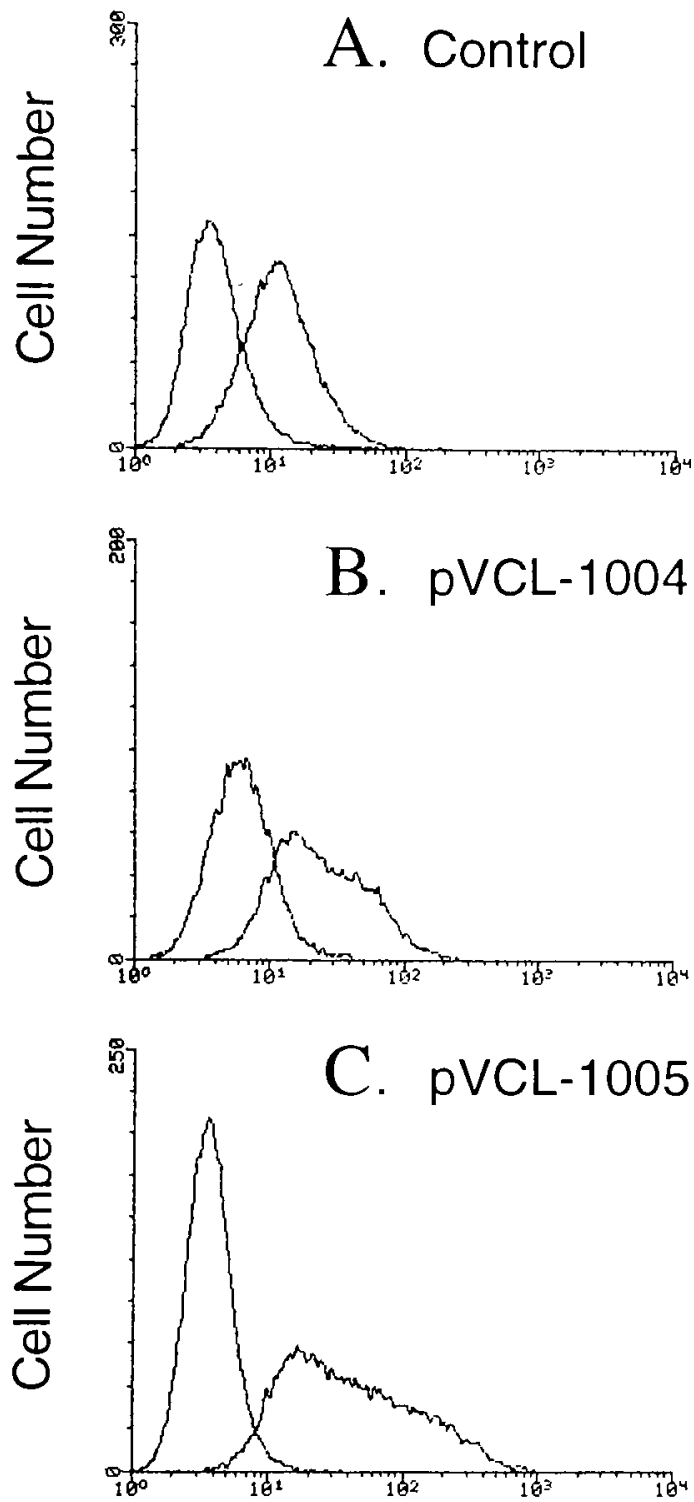

UM-449
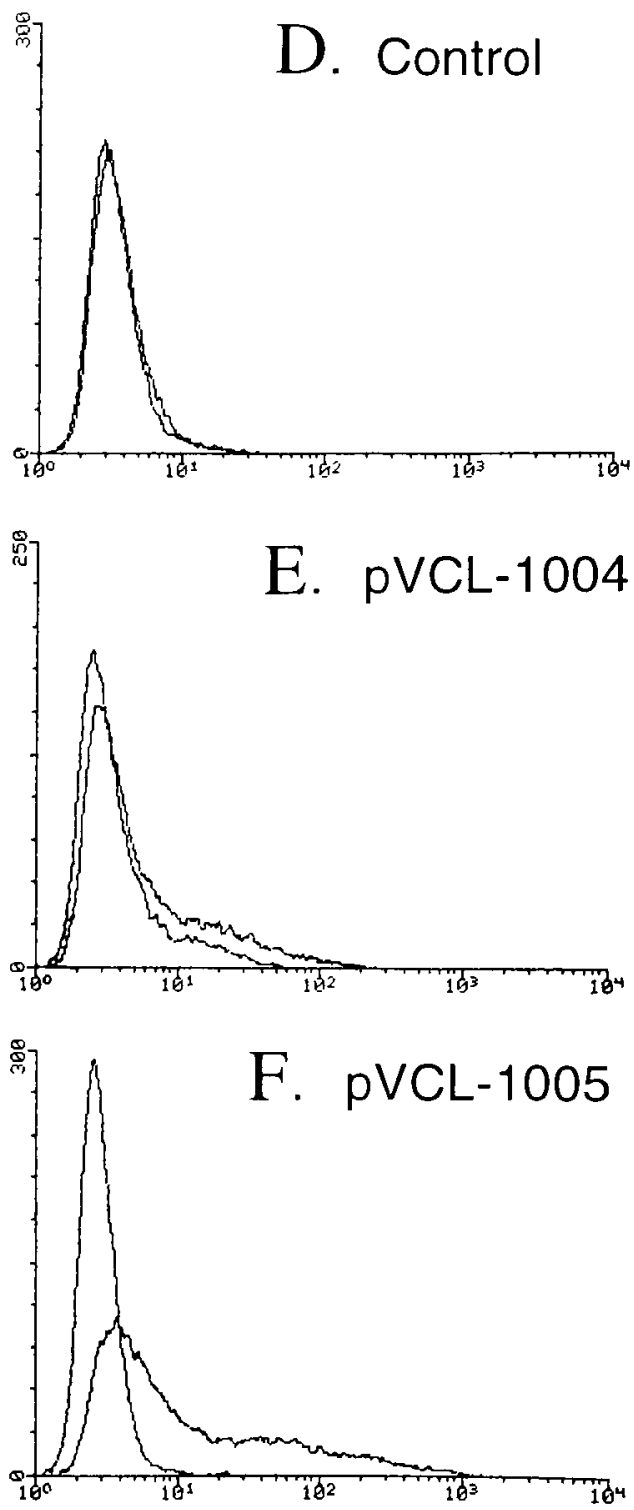

\section{Relative Fluorescence Intensity}

FIG. 2. In vitro HLA-B7 expression in transfected cells. L293 embryonal kidney cells $\left(\beta_{2} \mathrm{~m}\right.$ and HLA-B7 positive, A-C) or UM-449 melanoma cells ( $\beta_{2} \mathrm{~m}$ and HLA-B7 deficient, D-F) were transfected with the indicated plasmids and analyzed for HLA-B7 expression by flow cytometry following indirect fluorescent staining. Data acquired from the triplicate measurements of 10,000 cells are presented in combined single-parameter fluorescence histograms, comparing for each sample the negative control distribution (nonspecifically stained cells) and test distribution (specifically stained cells ) as defined in Materials and Methods. Cell number is shown on the $y$ axis, and relative fluorescence intensity is shown on the $x$ axis. In each panel, the nonspecific (negative control) distribution is represented by the curves with the highest peaks, while specifically stained cells are represented by the curves shifted to the right or displaying deviation from the normal distribution. Greater shifts to the right indicate greater fluorescence intensities; more complete separation between the negative and the positive distributions is an indication of a higher frequency of positive cells. A and D. Data from cells transfected with pRSVLacZ DNA. B and E. Data from cells transfected with pVCL-1004, containing the gene for the HLA-B7 heavy chain only. C and F. Data from cells transfected with pVCL-1005, containing the genes for both HLA-B7 and the $\beta_{2} \mathrm{~m}$ light chain. 

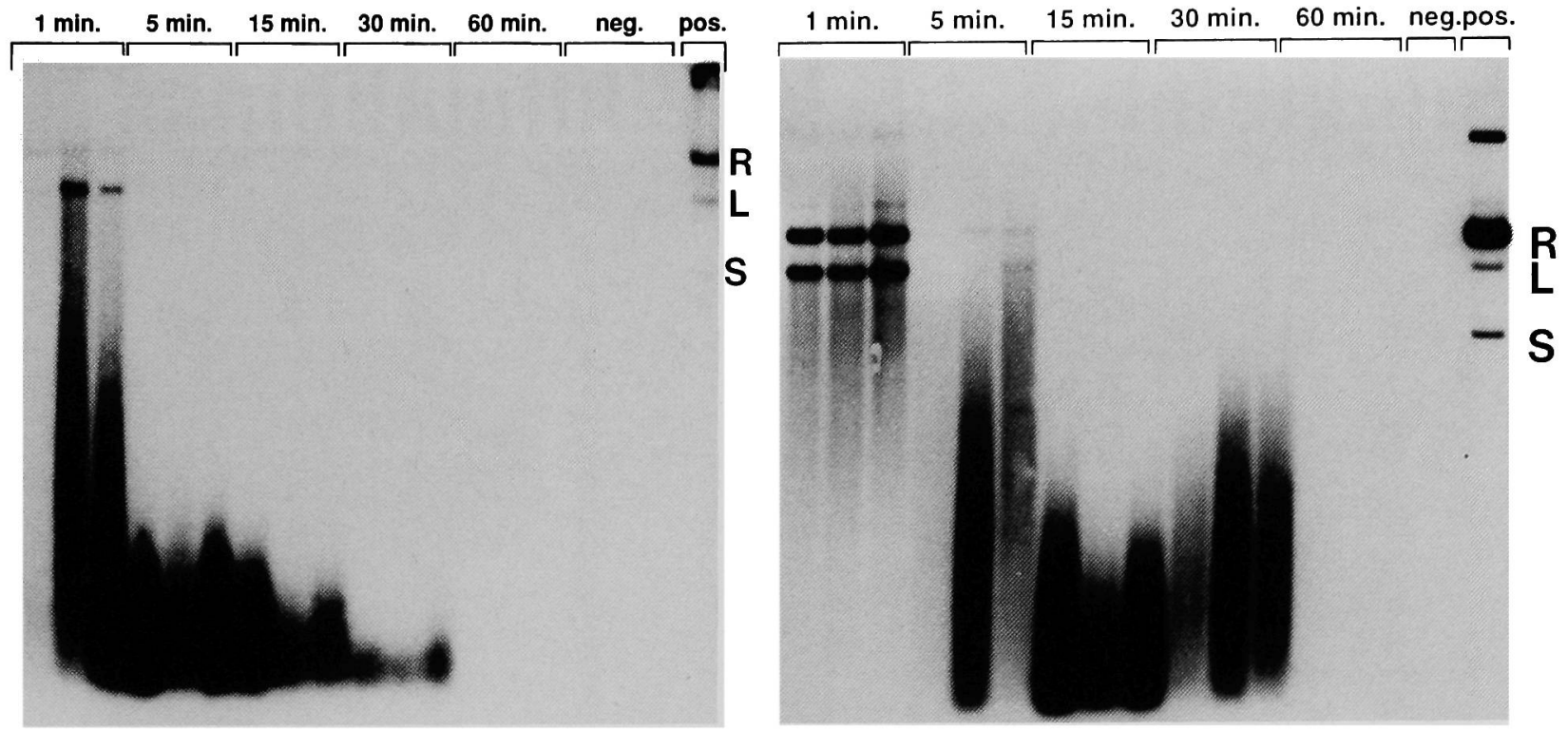

FIG. 3. Southern blot time course of plasmid in blood after intravenous injection. Following intravenous administration of $50 \mu g$ of plasmid DNA complexed with lipids, whole blood from three female ICR mice was isolated at each of the indicated times postinjection and DNA extracted. Five micrograms of each sample were separated on a $1 \%$ agarose gel. The transferred blot was probed with a random primed ${ }^{32}$ P-labeled plasmid fragment. A. pCMVintLux injected. B. VCL-1005 injected. neg., negative control uninjected mouse blood DNA; pos., positive control uninjected mouse blood mixed with supercoiled plasmid DNA complexed with lipids, and then extracted; S, supercoiled plasmid; L, linear; R, relaxed.

lower than intact plasmid. The rapid appearance of this lowmolecular-weight material showed that injected DNA was undergoing degradation within minutes. While degraded plasmid DNA sequences remained detectable at $30 \mathrm{~min}$ postinjection, the smear virtually disappeared from Southern blots by $60 \mathrm{~min}$. As a positive control, supercoiled plasmid DNA was added to blood in vitro, immediately frozen, and extracted with the rest of the samples (Fig. 3A). This positive control showed that even brief exposure to blood resulted in the immediate conversion of the supercoiled plasmid to relaxed and linear forms. The results demonstrate that i.v. administered supercoiled plasmid DNA was immediately subjected to degradation, probably from nucleases present in the serum. Degradation or tissue entrapment led to the disappearance of most of the plasmid from blood within $1 \mathrm{hr}$, as assayed by Southern blot.

Consistent with the results of the above experiments using $\mathrm{pC}$ MVintLux, pVCL-1005 was found to be rapidly degraded following i.v. administration (Fig. 3B). The half-life of the intact (linear or relaxed circular) plasmid was less than $5 \mathrm{~min}$, although degraded material was seen up to the 30-min timepoint. By $60 \mathrm{~min}$, no HLA-B7 hybridizable DNA was detected by this method. The consistency between results indicated that the rapid disappearance of plasmid DNA from blood was independent of the sequence.

\section{Pharmacokinetics of plasmid DNA in tissues}

To determine the fate of plasmid taken up by tissues, a pharmacokinetic analysis of plasmid in tissue was conducted following i.v. administration of either CMVintLux (data not shown) or VCL-1005. Total DNA was isolated from bone marrow, brain, heart, kidney, liver, lung, large intestine, small intestine, ovary/testis, spleen, and muscle at timepoints ranging between 5 min to 6 months postinjection. At the earliest time point (5-10 min), intact linear and relaxed circular plasmid DNA was detected in all tissues by Southern analysis (data not shown). Because the animals were not perfused prior to isolation of tissues, this detectability was due, in part, to residual plasmid circulating in the blood. The highest level of residual plasmid was detected in the heart, kidney, liver, lung, and spleen, which are highly vascularized tissues. However, within $1 \mathrm{hr}$, plasmid DNA was detected mainly in the bone marrow, heart, kidney, liver, lung, spleen and muscle, but not detected in the brain, large intestine, small intestine and ovaries. Data from individual female mice is shown for VCL-1005 in Fig. 4A, with results that were identical to pCMVintLux. Results were also consistent with similar tissues in male mice. Plasmid DNA remained detectable by Southern blot for up to $24 \mathrm{hr}$ postinjection, with the highest signal intensities found in the same tissues as at $1 \mathrm{hr}$ postinjection (Fig. 4B). However, the exposure times for the autoradiograms were about 17 times longer with the 24-hr postinjection samples than with the $1-\mathrm{hr}$ postinjection samples. Intact plasmid DNA remained detectable in tissues at $24 \mathrm{hr}$ postinjection.

Southern analyses of 7-day postinjection samples of pVCL1005 did not reveal any intact plasmid in tissues (Fig. 4C), as compared to the linearized positive control plasmid run in parallel. The nonspecific hybridization seen near the top of the blot was likely due to hybridization of mouse genomic DNA by the highly homologous human HLA-B7 probe, a consequence of long exposures of the autoradiogram. This hybridization was also seen in DNA from negative control mouse tissues (lactated Ringer's injected animal) in Fig. 4C, and therefore was not due to integration of plasmid into genomic DNA. The Southern blot technique has a sensitivity limit of about $1 \mathrm{pg}$ of plasmid DNA, assuming the signal is in one band. Since $10 \mu \mathrm{g} / \mathrm{lane}$ of total 
A

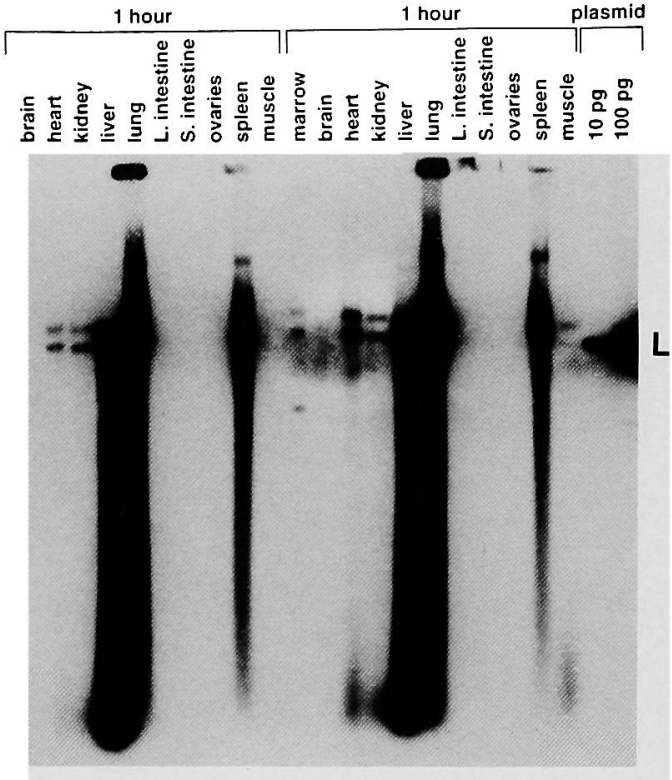

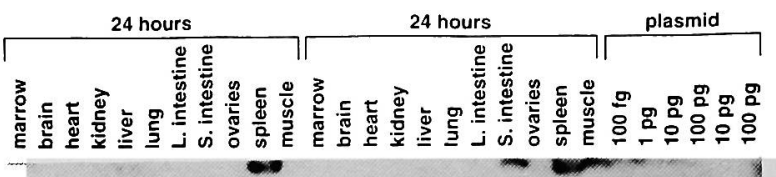

B

C

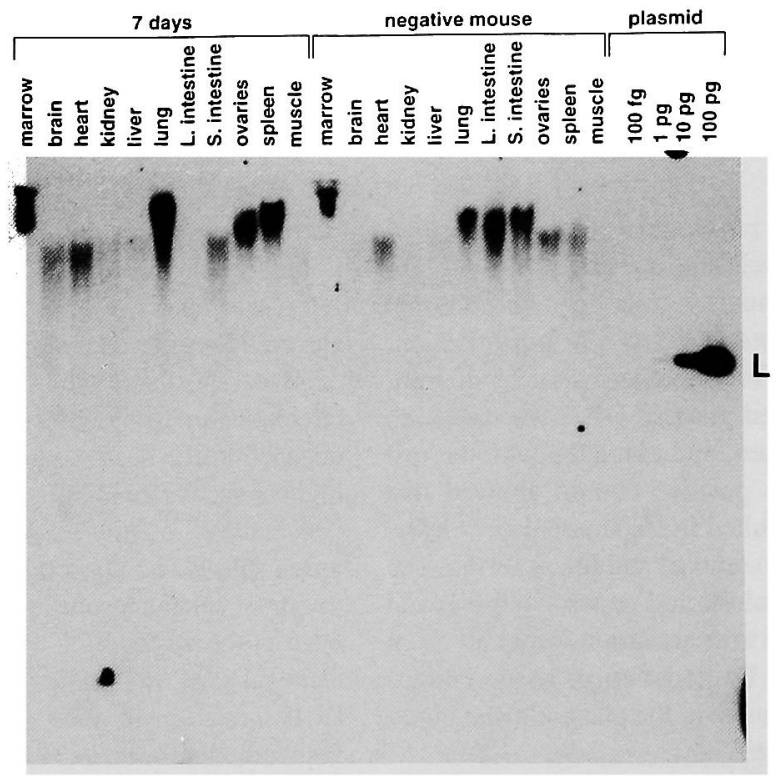

FIG. 4. Southern blots of tissue DNA following intravenous injection of VCL-1005. Following intravenous administration of 50 $\mu \mathrm{g}$ of plasmid DNA complexed with lipids, DNA from ICR female mice tissues was isolated at each of the indicated times postinjection. Results were consistent with similar tissues in male mice. Ten micrograms of each sample were separated on a $1 \%$ agarose gel. The transferred blots were probed with a random primed ${ }^{32} \mathrm{P}$-labeled fragment of the HLA-B7 gene. Positive control was plasmid DNA mixed into negative mouse genomic DNA. S, Supercoiled plasmid; L, linear; R, relaxed. A. 1-hr postinjection. B. $24 \mathrm{hr}$ postinjection. C. 7 days postinjection and uninjected.

genomic DNA was analyzed, detection of $1 \mathrm{pg}$ would represent 0.15 copies of plasmid per genome.

\section{PCR analyses}

To detect levels of plasmid that were less than $1 \mathrm{pg}$, samples collected later than $24 \mathrm{hr}$ postinjection were analyzed by PCR. PCR analysis was conducted using tissue samples collected 7 days, 28 days, and 6 months postinjection. ${ }^{32} \mathrm{P}$-labeled, plasmid-specific primers were chosen to amplify either the junction between the RSV promoter and HLA-B7 heavy-chain gene, or within the kanamycin resistance gene. PCR was quantitated by comparing the band intensities of the samples to plasmid standards run in parallel in a 32-cycle reaction. Although Southern analyses indicated that no intact plasmid DNA was present in tissues tested at time points beyond $24 \mathrm{hr}$, PCR results show the presence of plasmid sequences in all tissues at 7 and 28 days postinjection (Fig. 5). At 7 days, the samples that amplified to the greatest extent were the marrow, heart, kidney, liver, lung, spleen, and muscle. These same tissues were the ones in which 

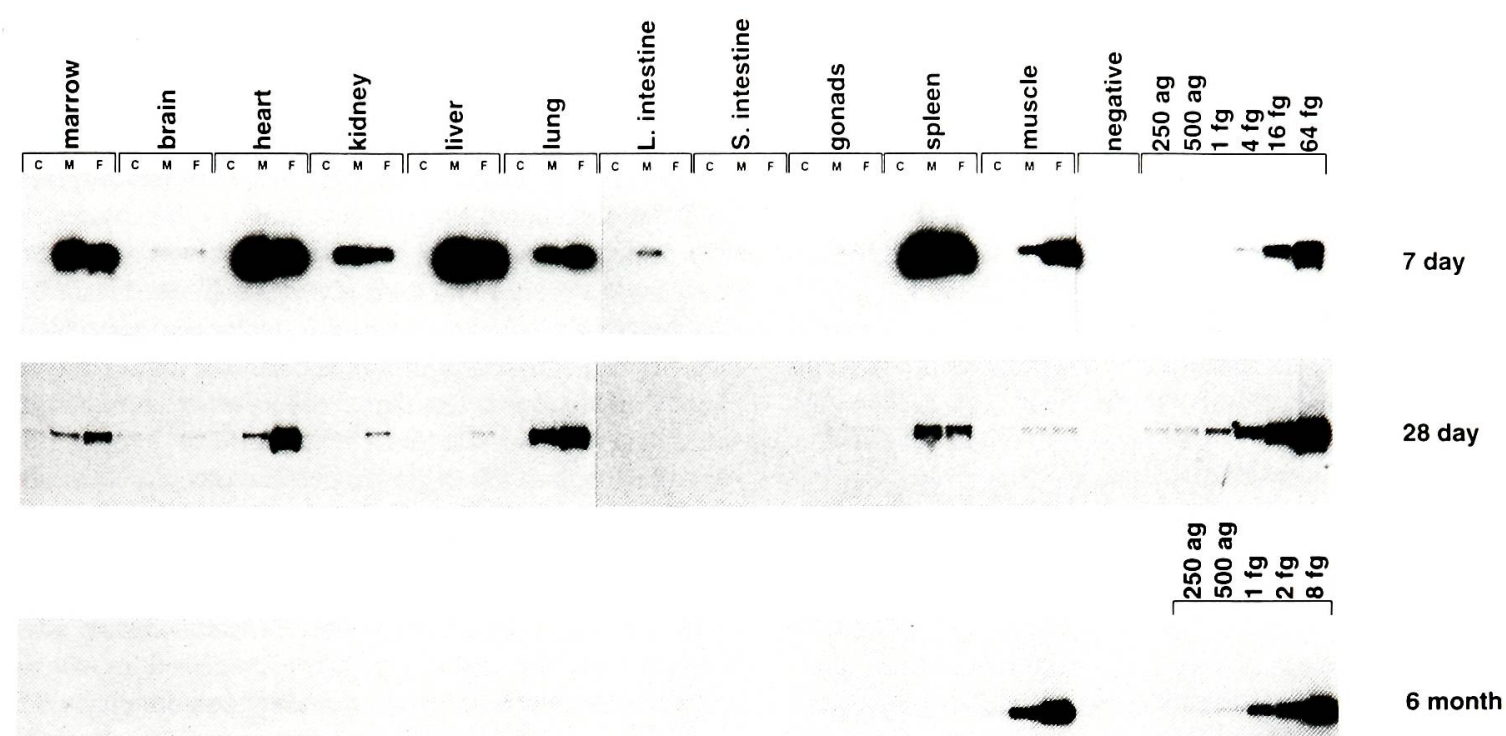

FIG. 5. PCR on extended timepoint postinjection tissue samples. Following intravenous injection of $50 \mu \mathrm{g}$ of VCL-1005, $1 \mu \mathrm{g}$ of genomic DNA from the indicated tissues was amplified by PCR containing ${ }^{32}$ P-labeled primers specific for the plasmid. Samples were separated on a nondenaturing $5.6 \%$ polyacrylamide gel. Seven-day, 28-day, and 6-month postinjection results are shown. C. Negative control tissue DNA; M, male; F, female. Lanes designated as negative are PCR products from uninjected tissue DNA. Standards are PCR products from purified plasmid amplified in $1 \mu \mathrm{g}$ of negative genomic DNA.

A

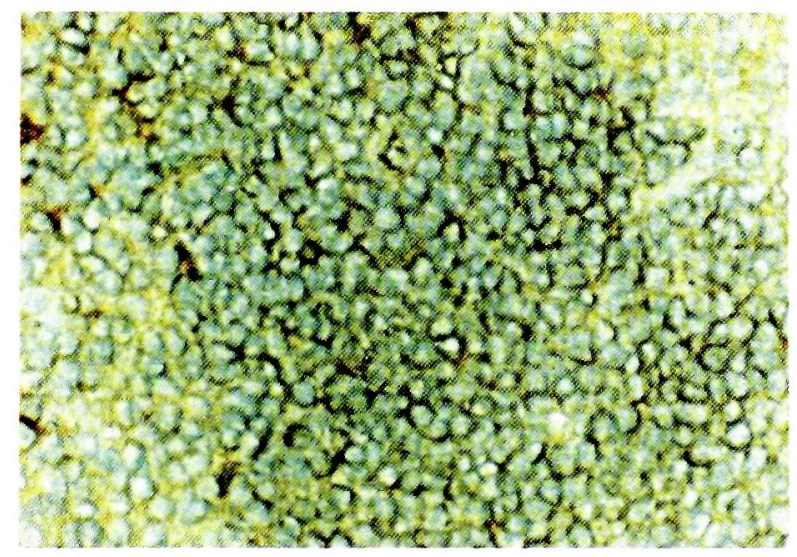

B

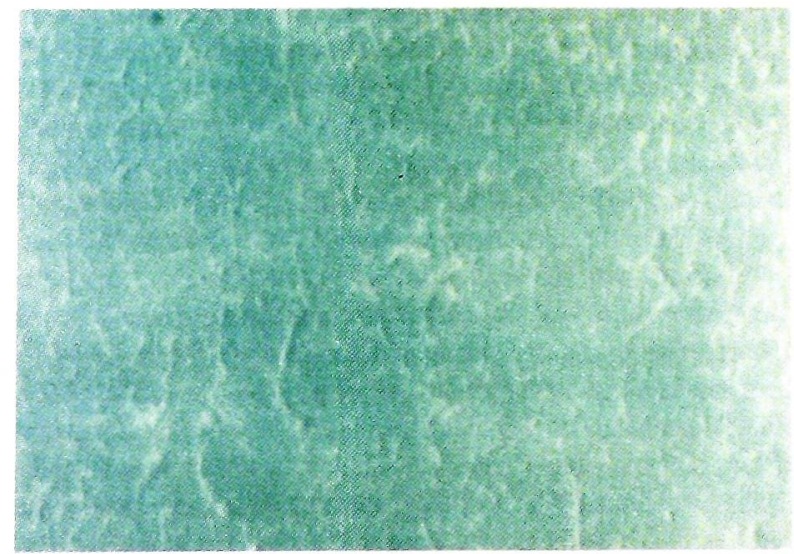

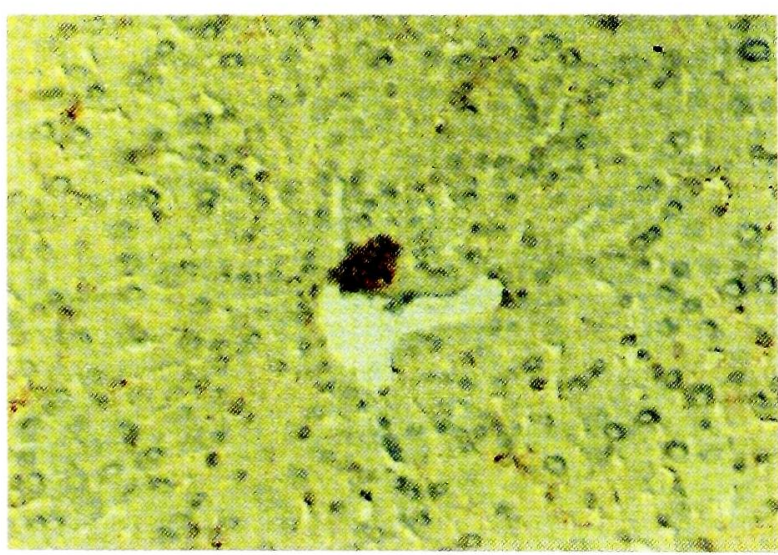

C

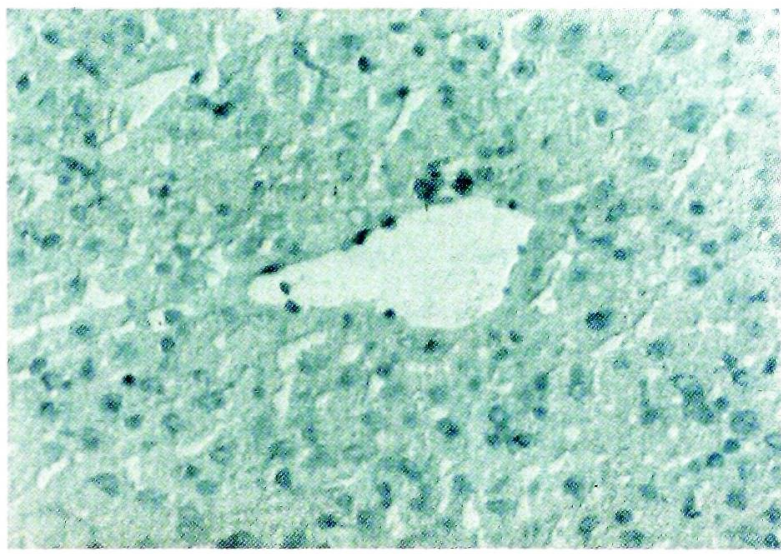

FIG. 6. Anti-HLA-B7 immunostaining of mouse tissues. Positive-control HLA-B7 heavy-chain/h $\beta_{2} \mathrm{~m}$ double transgenic mouse spleen (A) or liver (C) tissue were stained for HLA-B7 using the BB7.1 monoclonal antibody. Note extensive pericellular orange-yellow peroxidase staining. Spleen (B) and liver (D) tissues from ICR mice collected 24 hr following i.v. injection of VCL-1005 and stained with BB7.1 mAb were negative for HLA-B7 expression. 
Southern blots detected the greatest amount of plasmid at earlier timepoints. The range of residual plasmid, as estimated from band intensities, was $1 \mathrm{fg} / \mu \mathrm{g}$ sample in the brain, intestines, and gonads, to about $64 \mathrm{fg} / \mu \mathrm{g}$ sample in the marrow, heart, liver, spleen, and muscle, representing approximately 250 16,000 copies/ $\mu \mathrm{g}$ genomic DNA.

By 28 days, marrow, heart, kidney, liver, lung, spleen, and muscle still had the greatest amounts of amplifiable plasmid, although positive bands could be detected in all samples upon long autoradiographic exposure. The largest decrease from the 7-day samples appeared to be in the liver, and the smallest decrease in the lung. All 28-day tissues, with the exception of the lung, had less intense bands than the 7-day samples. The range of residual plasmid had diminished to less than $500 \mathrm{ag} / \mu \mathrm{g}$ in the brain, liver, intestines, and gonads, and to about $16 \mathrm{fg} / \mu \mathrm{g}$ genomic DNA in the marrow, heart, lung, and spleen. These amounts represent as much as a 128 -fold decrease from the 7-day level, equivalent to about $125-4,000$ copies/ $\mu \mathrm{g}$ of genomic DNA. In a mouse haploid genome of $3 \times 10^{9} \mathrm{bp}$, this represents about $0.0015-0.096$ copies/genome at 7 days, and about $0.0008-0.024$ copies/genome at 28 days. Variability existed within the equivalent tissues among different animals, but the level of plasmid was at or below the level of $100 \mathrm{fg} / \mu \mathrm{g}$ genomic DNA in all samples by 28 days. At 6 months postinjection, pVCL-1005 plasmid was detected predominantly in muscle, at approximately $2-8 \mathrm{fg} / \mu \mathrm{g}$ genomic DNA, or about 0.012 copies/genome (Fig. 5). Because of background and variability, we could not discern if tissues had fewer than 0.0004 copies/genome.

\section{Immunohistochemistry}

To determine if the plasmid remaining in the tissues was being expressed, immunohistochemical analyses were carried out on the tissues that retained the greatest amount of plasmid after i.v. administration of VCL-1005, specifically the heart, kidney, liver, lung, and spleen. The specificity of the HLA-B7 antibodies used in the present study was determined by immunostaining sections from tissues of HLA-B7 heavy-chain $/ \mathrm{h} \beta_{2} \mathrm{~m}$ double transgenic mice. Spleens from these double transgenic animals exhibited very strong pericellular HLA-B7 staining (Fig. 6A) and livers were moderately stained (Fig. 6C). In contrast, no HLA-B7 immunostaining was seen in any of the heart, kidney, lung (data not shown), spleen, and liver (Fig. 6B,D) tissues collected from mice 1 and 7 days after injection with VCL-1005. Therefore, despite the fact that the heart, kidney, liver, lung, and spleen contained some of the highest levels of intact pVCL-1005 plasmid DNA by Southern and PCR analyses at 1 and 7 days, none of these tissues was positive for HLA-B7 expression.

\section{DISCUSSION}

The consequence of direct intratumoral plasmid DNA injection may be the inadvertant introduction of DNA into other tissues via the bloodstream. Using plasmids encoding either a reporter gene or a complete MHC class I molecule, it was demonstrated that most of the plasmid DNA administered i.v. was rapidly degraded and cleared from blood within minutes and from tissues within hours of administration. The most significant decrease in detectable plasmid occurred during the first hour following injection.

Although the predominant plasmid conformation present in the DNA-lipid complex prior to injection was supercoiled, the only detectable intact forms in either the blood or tissues after injection were linear and relaxed circular DNA. Plasmid DNA was apparently subjected to serum nucleases in the blood almost immediately upon i.v. injection. The half-life of intact plasmid in blood was less than $5 \mathrm{~min}$. By Southern blot analyses, intact plasmid was present in blood as long as $15 \mathrm{~min}$ postinjection, but only degraded plasmid was present at $30 \mathrm{~min}$. By $60 \mathrm{~min}$, even the degraded material had been cleared from the blood, and there was no detectable retention of intact plasmid DNA by Southern blot analysis (sensitivity limit $=1 \mathrm{pg}$ ).

Specific tissues retained plasmid DNA immediately after i.v. injection, but the amount greatly diminished in all tissues within hours. One hour after i.v. administration, plasmid DNA was detected predominantly in the lung, spleen, liver, heart, kidney, marrow, and muscle. By Southern analysis, there was no detectable plasmid in the brain, large intestine, small intestine, or gonads at the 1-hr timepoint. Southern analysis also demonstrated that plasmid DNA remained in the liver, spleen, lung, marrow, and muscle, although at diminished levels, up to $24 \mathrm{hr}$ postinjection. At the 7- and 28-day timepoints, which could only be analyzed with the increased sensitivity of PCR, there was detectable plasmid in all tissues examined. However, most of the residual plasmid was detected in the same tissues as had been previously determined by Southern blot analysis. PCR analysis at the 6-month timepoint revealed that only muscle had any significant levels of plasmid above background. These results demonstrated that the amount of plasmid DNA remaining in the tissues following i.v. injection of $50 \mu \mathrm{g}$ plasmid drops significantly with less than 0.15 copies/genome within $24 \mathrm{hr}$, less than 0.096 copies/genome at 7 days, less than 0.024 copies/ genome at 28 days, and less than 0.012 copies/genome at 6 months.

Occasionally, plasmid DNA was detected in tissues other than the marrow, heart, kidney, liver, lung, spleen, and muscle in animals beyond the 28-day timepoint (data not shown). These findings were variable among animals and among different experiments, and probably represent contamination. Longer autoradiographic exposures at each timepoint revealed that all tissues amplified at very low levels of approximately $0.0003-$ 0.0004 copies/genome. These results were frequently indistinguishable from negative controls and thus were considered background. This low level may also represent nonspecific amplification from mouse genomic DNA, or variable low-level retention of plasmid in mouse tissues.

Although the amount of plasmid in the 6-month muscle samples appeared to be greater than in the 28-day samples, this does not represent an accumulation of plasmid in the muscle. More likely explanations are that variability exists among animals from different experiments, and that the PCR quantitation is only an estimate. Because skeletal muscle is one of the tissues that can be transfected in vivo upon direct intramuscular (i.m.) injection (Wolff et al., 1990, 1991; Acsadi et al., 1991; Jiao et al., 1992; Davis et al., 1993a,b), and plasmid DNA can be detected for greater than 1 year following direct i.m. injection, 
the continued presence of intact plasmid in muscle might be expected following i.v. injection.

While it was clear that some plasmid DNA was detectable by PCR for at least 6 months postinjection, there was no detectable HLA-B7 protein expression at earlier timepoints in tissues where the plasmid was observed to accumulate and when maximal expression was expected. Since immunostaining analysis is relatively insensitive compared to PCR, further studies on mRNA transcript levels following i.v. plasmid injection will need to be addressed. The observation that HLA-B7 protein expression levels were too low to be detected by immunostaining may suggest that levels were likely to be too low to elicit an immune response when administered systemically. Additionally, luciferase assays of mouse tissues following i.v. pCMVintLux injection did not result in luciferase expression in any tissues (unpublished observations).

In the present study, we have used a bicistronic plasmid, pVCL-1005, in which the cDNAs for HLA-B7 and $\beta_{2} \mathrm{~m}$ are under control of a single RSV promoter. The utility of this gene combination is demonstrated by higher MHC class I expression levels obtained when using this plasmid to transfect cells in vitro compared to using a plasmid encoding the HLA-B7 heavy chain alone. The plasmid pVCL-1005, which encodes both HLA-B7 heavy chain and $\beta_{2} \mathrm{~m}$ light chain, appeared to increase HLA-B7 surface expression in cells which contain low levels of endogenous $\beta_{2} \mathrm{~m}$. Additionally, even in cells that express endogenous $\beta_{2} m$, such as L293 cells, HLA-B7 expression levels increased following transfection with pVCL-1005.

Current injection technology does not permit exclusive transfection of tumor tissue. However, histological analyses of the liver, spleen, heart, and lung at timepoints at which peak expression was expected, did not reveal expression of HLA-B7 protein. It is possible that the expression levels were below the limit of detection with this technique. In vivo expression of this plasmid has been shown indirectly in BALB/c mice, which gave rise to antibodies to both heavy and light chains of the HLA-B7 protein following direct i.m. injection pVCL-1005 (unpublished observations). However, in a companion safety study, none of the animals that received an i.v. administration of VCL-1005 exhibited signs of autoimmune attack (see accompanying paper by Parker et al.).

The intravenous injection of DNA with cationic lipids has been reported previously to result in expression of a chloramphenicol acetyltransferase (CAT) reporter gene product in many mouse tissues $48 \mathrm{hr}$ postinjection (Zhu et al., 1993). Moreover, these investigators were able to detect plasmid DNA sequences by PCR 63 days postinjection in lung, heart, and spleen. Although the PCR results from the present study were consistent with DNA detection results in terms of plasmid localization, expression of plasmid encoded HLA-B7 was not found in tissues following i.v. administration of VCL-1005. Future investigations should elucidate the contributions made by factors such as mRNA and protein stability to the levels of protein expressed in vivo (Ledley and Ledley, 1994).

This study represents the first systematic in vivo pharmacokinetic study of intravenously injected DNA complexed with cationic lipids and was presented in support of ongoing clinical trials. It is relevant to many current and future gene therapy trials utilizing direct injection of plasmid DNA and should facilitate understanding of the safety of this procedure.

\section{ACKNOWLEDGMENTS}

We would like to thank Dr. Per Peterson of The Scripps Research Institute for his generous gift of the HLA-B $7 / \mathrm{h} \beta_{2} \mathrm{~m}$ transgenic mice.

\section{REFERENCES}

ACSADI, G., JIAO, S., JANI, A., DUKE, D., WILlIAMS, P., CHONG, W., and WOLFF, J.A. (1991). Direct gene transfer and expression into rat heart in vivo. New Biol 3, 71-81.

AUSUBEL, F.M., BRENT, R., KINGSTON, R.E., MOORE, D.D., SEIDMAN, J.G., SMITH, J.A., and STRUHL, K., eds. (1987). Current Protocols in Molecular Biology. John Wiley \& Sons, Inc., New York.

BOSHART, M., WEBER, F., JAHN, G., DORSCH-HASLER, K., FLECKENSTEIN, B., and SCHAFFNER, W. (1985). A very strong enhancer is located upstream of an immediate early gene of human cytomegalovirus. Cell 41, 521-530.

CHAPMAN, B.S., THAYER, R.M., VINCENT, K.A., and HAIGWOOD, N.L. (1991). Effect of intron A from human cytomegalovirus (Towne) immediate early gene on heterologous expression in mammalian cells. Nucleic Acids Res. 19, 3979-3986.

DAVIS, H.L., WHALEN, R.G., and DEMENEIX, B.A. (1993a). Direct gene transfer into skeletal muscle in vivo: Factors affecting efficiency of transfer and stability of expression. Hum. Gene. Ther. 4, 151-159.

DAVIS, H.L., DEMENEIX, B.A., QUANTIN, B., COULOMBE, J., and WHALEN, R.G. (1993b) Plasmid DNA is superior to viral vectors for direct gene transfer into adult mouse skeletal muscle. Hum. Gene Ther. 4, 733-740.

DEWET, J.R., WOOD, K.V., DELUCA, M., HELINSKI, D.R., and SUBRAMANI, S. (1987). Firefly luciferase gene: structure and expression in mammalian cells. Mol. Cell. Biol. 7, 725-737.

ELROY-STEIN, O., FUERST, TR, and MOSS, B. (1989). Capindependent translation of mRNA conferred by encephalomyocarditisvirus $5^{\prime}$ sequence improves the performance of the vaccinia virus/bacteriophage T7 hybrid expression system. Proc. Natl. Acad. Sci. USA 86, 6126-6130.

FELGNER.P.L. (1990). Particulate systems and polymers for in vitro and in vivo delivery of polynucleotides. Adv. Drug Delivery Rev. 5, 167-187.

FELGNER, P.L., GADEK, T.R., HOLM, M., ROMAN, R., CHAN, H.W., WENZ, M., NORTHROP, J.P., RINGOLD, G.M., and DANIELSEN, M. (1987). Lipofection: A highly efficient, lipidmediated DNA transfection procedure. Proc. Natl. Acad. Sci. USA 84, 7413-7417.

FELGNER, J.H., KUMAR, R., SRIDHAR, C.N., WHEELER, C.J., TSAI, Y.J., BORDER, R., RAMSEY, P., MARTIN, M., and FELGNER, P.L. (1994). Enhanced gene delivery and mechanism studies with a novel series of cationic lipid formulations. J. Biol. Chem. 269, 2550-2561.

FUNA, K., GAZDAR, A.F., MINNA, J.D., and LINNOILA, R.I. (1986). Paucity of beta 2-microglobulin expression on small cell lung cancer, bronchial carcinoids and certain other neuroendocrine tumors. Lab Invest. 55, 186-193.

GHATTAS, I.R., SANES, J.R., and MAJORS, J.E. (1991). The encephalomyocarditis virus internal ribosome entry site allows efficient coexpression of two genes from a recombinant provirus in cultured cells and in embryos. Mol. Cell. Biol. 11, 5848-5859.

GHAZAL, P., LUBON, H., FLECKENSTEIN, B., and HENNIGHAUSEN, L. (1987). Binding of transcription factors and creation of a large nucleoprotein complex on the human cytomegalovirus enhancer. Proc. Natl. Acad. Sci. USA 84, 3658-3662. 
GORDON, D.F., QUICK, D.P., ERWIN, C.R., DONELSON, J.E., and MAURER, R.A. (1983). Nucleotide sequence of the bovine growth hormone chromosomal gene. Mol. Cell. Endocrinol. 33, 81-95.

GORMAN, C., PADMANABHAN, R., and HOWARD, B.H. (1983). High efficiency DNA-mediated transformation of primate cells. Science 221, 551-553.

HORN, N., MEEK, J., BUDAHAZI, G., and MARQUET, M. (1995). Cancer gene therapy using plasmid DNA: Purification of DNA for human clinical trials. Hum. Gene Ther. 61, 565-573.

ISAKOV, N., KATZAV, S., FELDMAN, M., and SEGAL, S.J. (1983). Loss of expression of transplantation antigens encoded by the $\mathrm{H}-2 \mathrm{~K}$ locus on Lewis lung carcinoma cells and its relevance to the tumor's metastatic properties. J. Natl. Canc. Inst. 71, 139-145.

JANG, S.K., KRAUSSLICH, H-G., NICKLIN, M.J.H., DUKE, G.M., PALMENBERG, A.C., and WIMMER, E. (1988). A segment of the $5^{\prime}$ nontranslated region of encephalomyocarditis virus RNA directs internal entry of ribosomes during in vitro translation. $J$. Virol. 62, 2636-2643.

JANG, S.K., DAVIES, M.V., KAUFMAN, R.J., and WIMMER, E. (1989). Initiation of protein synthesis by internal entry of ribosomes into the 5' nontranslated region of encephalomyocarditis virus RNA in vivo. J. Virol. 63, 1651-1660.

JIAO, S., WHLLIAMS, P., BERG, R.K., HODGEMAN, B.A., LIU, L., REPETTO, G., and WOLFF, J.A. (1992). Direct gene transfer into nonhuman primate myofibers in vivo. Hum. Gene Ther. 3, 21-33.

LAMPSON, L.A., FISHER, C.A., and WHELAN, J.P. (1983). Striking paucity of HLA-A, B, C and beta 2-microglobulin on human neuroblastoma cell lines. J. Immunol. 130, 2471-2478.

LEDLEY, T.S., and LEDLEY, F.D. (1994). Multicompartment, numerical model of cellular events in the pharmacokinetics of gene therapies. Hum. Gene Ther. 5, 679-691.

MANTHORPE, M., CORNEFERT-JENSEN, F., HARTIKKA, J., FELGNER, J., RUNDELL, A., MARGALITH, M. , and DWARKI, V. (1993). Gene therapy by intramuscular injection of plasmid DNA: Studies on firefly luciferase gene expression in mice. Hum. Gene Ther. 4, 419-431.

MORGAN, R.A., COUTURE, L., ELROY-STEIN, O., RAGHEB, J., MOSS, B., and ANDERSON, W.F. (1992). Retroviral vectors containing putative internal ribosome entry sites: Development of a polycistronic gene transfer system and applications to human gene therapy. Nucleic Acids Res. 20, 1293-1299.

NABEL, E.G., GORDON, D., YANG, Z-Y., XU, L., SAN, H., PLAUTZ, G.E., WU, B-Y., GAO, X., HUANG, L., and NABEL, G.J. (1992a). Gene transfer in vivo with DNA-liposome complexes: lack of autoimmunity and gonadal localization. Hum. Gene Ther. 3, 649-656.

NABEL, G.J., CHANG, A., NABEL, E.G., PLAUTZ, G., FOX, B.A., HUANG, L., and SHU, S. (1992b). Immunotherapy of malignancy by in vivo gene transfer into tumors. Hum. Gene Ther. 3, $399-410$.

NABEL, G.J., NABEL, E.G., YANG, Z-Y., FOX, B.A., PLAUTZ, G.E., GAO, X., HUANG, L., SHU, S., GORDON, D., and CHANG, A.E. (1993). Direct gene transfer with DNA liposome complexes in melanoma: Expression, biologic activity, and lack of toxicity in humans. Proc. Natl. Acad. Sci. USA 90, 11307-11311.

NOMURA, N., YAMAGISHI, H., and OKA, A. (1978). Isolation and characterization of transdueing eoliphage fd earrying a kanamycin resistance gene. Gene 3, 39-51.

NORTON, P.A., and COFFIN, J.M. (1985). Bacterial beta-galactosidase as a marker ef Rous sarcoma virus gene expression and replication. Mol. Cell. Biol. 5, 281-290.
PARKER, S.E., VAHLSING, H.L., SERFILIPPI, L.M., FRANKLIN, C.L., DOH, S.G., GROMKOWSKI, S.H., LEW, D., MANTHORPE, M., and NORMAN, J. (1995). Cancer gene therapy using plasmid DNA: Safety evaluation in rodents and non-human primates. Hum. Gene Ther. 6, 575-590.

PARKS, G.D., DUKE, G.M., and PALMENBERG, A.C. (1986). Encephalomyocarditis virus 3C protease: efficient cell-free expression from clones which link viral 5 ' noncoding sequences to the P3 region. J. Virol. 60, 376-384.

PLAUTZ, G.E., YANG, Z-Y., WU, B.Y., GAO, X., HUANG, L., and NABEL, G.J. (1993). Immunotherapy of malignancy by in vivo gene transfer into tumors. Proc. Natl. Acad. Sci. USA 90, 46454649.

SCHMIDT, W., LEBEN, L., ATFIELD, G., and FESTENSTEIN, H.H. (1981). Variation of expression of histocompatibility antigens on tumor cells: Absence of $\mathrm{H}-2 \mathrm{Kk}$-gene products from a gross-virusinduced leukemia in BALB.K. Immunogen. 14, 323-329.

STEWART, M.J., PLAUTZ, G.E., DEL BUONO, L., YANG, Z-Y., XU, L., GAO, X., HUANG, L., NABEL, E.G., and NABEL, G.J. (1992). Gene transfer in vivo with DNA-liposome complexes: safety and acute toxicity in mice. Hum. Gene Ther. 3, 267-275.

SUGGS, S.V., WALLACE,-R.B., HFOSE, T., KAWASHIMA, E.H., and ITAKURA, K. (1981). Use of synthetic oligonucleotides as hybridization probes: isolation of cloned cDNA sequences for human $\beta 2$ microglobulin. Proc. Natl. Acad. Sci. USA 78, 66136617.

THOMSEN, D.R., STENBERG, R.M., GOINS, W.F., and STINSKI, M.F. (1984). Promoter-regulatory region of the major immediate early gene of human cytomegalovirus. Proc. Natl. Acad. Sci. USA 81, 659-663.

VILE, R.G., and HART, I.R. (1993). In vitro and in vivo targeting of gene expression to melanoma cells. Cancer Res. 53, 962-967

WANG, C.Y., and HUANG, L. (1989) Highly efficient DNA delivery mediated by pH-sensitive immunoliposomes. Biochemistry 28 , 9508-9514.

WILLIAMS, D.B., BARBER, B.H., FLAVELL, R.A., and ALLEN, $H$. (1989). Role of $\beta 2$-microglobulin in the intracellular transport and surface expression of murine class I histocompatibility molecules. J. Immunol. 142, 2796-2806.

WOLFF, J.A., MALONE, R.W., WILLIAMS, P., CHONG, W., ACSADI, G., JANI, A., and FELGNER, P.L. (1990). Direct gene transfer into mouse muscle in vivo. Science $247,1465-1468$.

WOLFF, J.A., WILLIAMS, P., ACSADI, G., JIAO, S., JANI, A., and CHONG, W. (1991). Conditions affecting direct gene transfer into rodent muscle in vivo. BioTechniques 11, 474-485.

ZAMOYSKA, R., and PARNES, J.R. (1988). Rescue of Daudi cell HLA expression by transfection of the mouse $\beta 2$-microglobulin gene. J. Exp. Med. 167, 288-299.

ZHU, N., LIGGITT, D., LIU, Y., and DEBS, R. (1993). Systemic gene expression after intravenous DNA delivery into adult mice. Science 261, 209-211

Address reprint requests to: Dr. Denise Lew Vical, Inc.

9373 Towne Centre Drive Suite 100

San Diego, CA 92121

Received for publication October 17, 1994; accepted after revision January 27, 1995. 


\section{This article has been cited by:}

1. Iris Baumgartner, Nicolas Chronos, Anthony Comerota, Timothy Henry, Jean-Paul Pasquet, François Finiels, Anne Caron, Jean-François Dedieu, Richard Pilsudski, Pia Delaère. 2009. Local Gene Transfer and Expression Following Intramuscular Administration of FGF-1 Plasmid DNA in Patients With Critical Limb Ischemia. Molecular Therapy 17:5, 914-921. [CrossRef]

2. Kaley D. Wilson, Susan D. de Jong, Mikameh Kazem, Ryan Lall, Michael J. Hope, Pieter R. Cullis, Ying K. Tam. 2009. The combination of stabilized plasmid lipid particles and lipid nanoparticle encapsulated CpG containing oligodeoxynucleotides as a systemic genetic vaccine. The Journal of Gene Medicine 11:1, 14-25. [CrossRef]

3. Agop Y Bedikian, Michele Del Vecchio. 2008. Allovectin-7 therapy in metastatic melanoma. Expert Opinion on Biological Therapy 8:6, 839-844. [CrossRef]

4. Ma-feng Liu, Xiu-ping Wu, Xue-lin Wang, Yan-ling Yu, Wei-fang Wang, Qi-jun Chen, Pascal Boireau , Ming-yuan Liu . 2008. The Functions of Deoxyribonuclease II in Immunity and Development The Functions of Deoxyribonuclease II in Immunity and Development. DNA and Cell Biology 27:5, 223-228. [Abstract] [PDF] [PDF Plus]

5. Joyce C. Chen, Shelley R. Winn, Xi Gong, Wayne H. Ozaki. 2007. rhBMP-4 Gene Therapy in a Juvenile Canine Alveolar Defect Model. Plastic and Reconstructive Surgery 120:6, 1503-1509. [CrossRef]

6. Adriano R. Azzoni, Sofia C. Ribeiro, Gabriel A. Monteiro, Duarte M.F. Prazeres. 2007. The impact of polyadenylation signals on plasmid nuclease-resistance and transgene expression. The Journal of Gene Medicine 9:5, 392-402. [CrossRef]

7. Yoshikuni Yonenaga, Akira Mori, Akihisa Fujimoto, Satoshi Nagayama, Tsuyoshi Tachibana, Hisashi Onodera, Shinji Uemoto. 2007. The administration of naked plasmid DNA into the liver induces antitumor innate immunity in a murine liver metastasis model. The Journal of Gene Medicine 9:4, 299-307. [CrossRef]

8. Eun Sung Kang, Chae Young Kim, Seon Beom Kim, Se Jin Im, Se Hwan Yang, Young Chul Sung, Byong Moon Kim. 2007. In vivo kinetics and biodistribution of HB-110, a novel HBV DNA vaccine, after administration in Mice. Archives of Pharmacal Research 30:3, 355-360. [CrossRef]

9. Rene Gonzalez, Laura Hutchins, John Nemunaitis, Michael Atkins, Paul O. Schwarzenberger. 2007. Phase 2 trial of Allovectin-7 in advanced metastatic melanoma. Melanoma Research 16:6, 521-526. [CrossRef]

10. Tomoaki Yoshikawa, Naoki Okada, Shinsaku Nakagawa. 2007. Fusogenic liposomes and their suitability for gene delivery. Future Lipidology 1:6, 735-742. [CrossRef]

11. Sarah E McNeil, Yvonne Perrie. 2006. Gene delivery using cationic liposomes. Expert Opinion on Therapeutic Patents 16:10, 1371-1382. [CrossRef]

12. Mi-Kyung Son, Jae-Hoon Choi, Dong-Sop Lee, Chae-Young Kim, Seul-Min Choi, Kyung-Koo Kang, Jonghoe Byun, Duk-Kyung Kim, Byong-Moon Kim. 2005. Pharmacokinetics and Biodistribution of a pGT2-VEGF Plasmid DNA After Administration in Rats. Journal of Cardiovascular Pharmacology 46:5, 577-584. [CrossRef]

13. Wenhao Li, Tatsuhiro Ishida, Yurie Okada, Naoto Oku, Hiroshi Kiwada. 2005. Increased Gene Expression by Cationic Liposomes (TFL-3) in Lung Metastases Following Intravenous Injection. Biological \& Pharmaceutical Bulletin 28:4, 701-706. [CrossRef]

14. Kristin C. Backstrom, Alicia L. Bertone, Erik R. Wisner, Stephen E. Weisbrode. 2004. Response of induced bone defects in horses to collagen matrix containing the human parathyroid hormone gene. American Journal of Veterinary Research 65:9, 1223-1232. [CrossRef]

15. David A. Dean . 2003. Electroporation of the Vasculature and the LungElectroporation of the Vasculature and the Lung. DNA and Cell Biology 22:12, 797-806. [Abstract] [PDF] [PDF Plus]

16. Byong -Moon Kim, Dong -Sop Lee, Jae -Hoon Choi, Chae -Young Kim, Miwon Son, You -Suk Sun, Kwan -Hyuck Baek, Ki -Seok Park, Young -Chul Sung, Won -Bae Kim. 2003. In Vivo kinetics and biodistribution of a HIV-1 DNA vaccine after administration in mice. Archives of Pharmacal Research 26:6, 493-498. [CrossRef]

17. Michael Bergen, Robert Chen, Rene Gonzalez. 2003. Efficacy and safety of HLA-B7/ $\beta-2$ microglobulin plasmid DNA/lipid complex (Allovectin-7 $\mathbb{B}$ ) in patients with metastatic melanoma. Expert Opinion on Biological Therapy 3:2, 377-384. [CrossRef] 
18. Tatsufumi USUI, Satoru KONNAI, Shigeru TAJIMA, Shinobu WATARAI, Yoko AIDA, Kazuhiko OHASHI, Misao ONUMA. 2003. Protective Effects of Vaccination with Bovine Leukemia Virus (BLV) Tax DNA Against BLV Infection in Sheep. Journal of Veterinary Medical Science 65:11, 1201-1205. [CrossRef]

19. Crispin R. Dass , Mark A. Burton . 2002. A Model for Evaluating Selective Delivery of Plasmid DNA to Tumours via the VasculatureA Model for Evaluating Selective Delivery of Plasmid DNA to Tumours via the Vasculature. Cancer Biotherapy \& Radiopharmaceuticals 17:5, 501-505. [Abstract] [PDF] [PDF Plus]

20. Feng Liu, Leaf Huang. 2001. Improving plasmid DNA-mediated liver gene transfer by prolonging its retention in the hepatic vasculature. The Journal of Gene Medicine 3:6, 569-576. [CrossRef]

21. Ulrich R. Hengge, Bjorn Dexling, Alireza Mirmohammadsadegh. 2001. Safety and Pharmacokinetics of Naked Plasmid DNA in the Skin: Studies on Dissemination and Ectopic Expression1. Journal of Investigative Dermatology 116:6, 979-982. [CrossRef]

22. I Baumgartner, JM Isner. 2001. SOMATIC GENE THERAPY IN THE CARDIOVASCULAR SYSTEM. Annual Review of Physiology 63:1, 427-450. [CrossRef]

23. Holger H. Roehl, Martha E. I. Leibbrandt, Judith S. Greengard, Edgar Kamantigue, William G. Glass, Martin Giedlin , Kim Boekelheide, Dale E. Johnson, Douglas J. Jolly, Nancy C. Sajjadi . 2000. Analysis of Testes and Semen from Rabbits Treated by Intravenous Injection with a Retroviral Vector Encoding the Human Factor VIII Gene: No Evidence of Germ Line TransductionAnalysis of Testes and Semen from Rabbits Treated by Intravenous Injection with a Retroviral Vector Encoding the Human Factor VIII Gene: No Evidence of Germ Line Transduction. Human Gene Therapy 11:18, 2529-2540. [Abstract] [PDF] [PDF Plus]

24. Jeffrey O. Hollinger, Shelley Winn , Jeffrey Bonadio . 2000. Options for Tissue Engineering to Address Challenges of the Aging SkeletonOptions for Tissue Engineering to Address Challenges of the Aging Skeleton. Tissue Engineering 6:4, 341-350. [Abstract] [PDF] [PDF Plus]

25. Wendy T. Collard, Yongsheng Yang, Kai Y. Kwok, Youmie Park, Kevin G. Rice. 2000. Biodistribution, metabolism, and in vivo gene expression of low molecular weight glycopeptide polyethylene glycol peptide DNA co-condensates. Journal of Pharmaceutical Sciences 89:4, 499-512. [CrossRef]

26. Stephen A. White, Albert F. LoBuglio, Ramin B. Arani, Mary J. Pike, Susan E. Moore, Daunte L. Barlow, Robert M. Conry. 2000. Induction of anti-tumor immunity by intrasplenic administration of a carcinoembryonic antigen DNA vaccine. The Journal of Gene Medicine 2:2, 135-140. [CrossRef]

27. Gaetano Giammona, Gennara Cavallaro, Giovanna Pitarresi, Elisa Pedone. 2000. Cationic copolymers of ?,?-poly-(N-2-hydroxyethyl)-DL-aspartamide (PHEA) and ?,?-polyasparthylhydrazide (PAHy): synthesis and characterization. Polymer International 49:1, 93-98. [CrossRef]

28. Marja Laitinen, Juha Hartikainen, Mikko O. Hiltunen, Jaakko Eranen, Mikko Kiviniemi , Outi Narvanen , Kimmo Makinen, Hannu Manninen, Mikko Syvanne, John F. Martin, Markku Laakso, Seppo Yla-Herttuala . 2000. Catheter-Mediated Vascular Endothelial Growth Factor Gene Transfer to Human Coronary Arteries after AngioplastyCatheter-Mediated Vascular Endothelial Growth Factor Gene Transfer to Human Coronary Arteries after Angioplasty. Human Gene Therapy 11:2, 263-270. [Abstract] [PDF] [PDF Plus]

29. Holly M Horton, Suezanne E Parker, Mary K Wloch, Jon A Norman. 2000. DNA vaccines for cancer therapy. Expert Opinion on Investigational Drugs 8:12, 2017-2026. [CrossRef]

30. Mary E. Barry, Dasein Pinto-Gonzalez , Frank M. Orson, Gregory J. McKenzie, George R. Petry , Michael A. Barry . 1999. Role of Endogenous Endonucleases and Tissue Site in Transfection and CpG-Mediated Immune Activation after Naked DNA InjectionRole of Endogenous Endonucleases and Tissue Site in Transfection and CpG-Mediated Immune Activation after Naked DNA Injection. Human Gene Therapy 10:15, 2461-2480. [Abstract] [PDF] [PDF Plus]

31. Terrie Martin , Suezanne E. Parker, Richard Hedstrom , Thong Le, Stephen L. Hoffman , Jon Norman , Peter Hobart, Denise Lew . 1999. Plasmid DNA Malaria Vaccine: The Potential for Genomic Integration after Intramuscular InjectionPlasmid DNA Malaria Vaccine: The Potential for Genomic Integration after Intramuscular Injection. Human Gene Therapy 10:5, 759-768. [Abstract] [PDF] [PDF Plus]

32. Suezanne E. Parker, Flavia Borellini , Martin L. Wenk, Peter Hobart, Stephen L. Hoffman, Richard Hedstrom , Thong Le , Jon A. Norman . 1999. Plasmid DNA Malaria Vaccine: Tissue Distribution and Safety Studies in Mice 
and RabbitsPlasmid DNA Malaria Vaccine: Tissue Distribution and Safety Studies in Mice and Rabbits. Human Gene Therapy 10:5, 741-758. [Abstract] [PDF] [PDF Plus]

33. Mark Selby, Christopher M Walker, Jeffrey B Ulmer. 1999. Mechanisms of action of DNA vaccines. Expert Opinion on Investigational Drugs 7:12, 1987-1995. [CrossRef]

34. Kerry M. Barnhart, Jukka Hartikka, Marston Manthorpe, Jon Norman, Peter Hobart. 1998. Enhancer and Promoter Chimeras in Plasmids Designed for Intramuscular Injection: A Comparative In Vivo and In Vitro StudyEnhancer and Promoter Chimeras in Plasmids Designed for Intramuscular Injection: A Comparative In Vivo and In Vitro Study. Human Gene Therapy 9:17, 2545-2553. [Abstract] [PDF] [PDF Plus]

35. Kerry M. Barnhart, Jukka Hartikka , Marston Manthorpe , Jon Norman , Peter Hobart . 1998. Enhancer and Promoter Chimeras in Plasmids Designed for Intramuscular Injection: A Comparative In Vivo and In Vitro StudyEnhancer and Promoter Chimeras in Plasmids Designed for Intramuscular Injection: A Comparative In Vivo and In Vitro Study. Human Gene Therapy 9:17, 2545-2553. [Abstract] [PDF] [PDF Plus]

36. Margarete Arras, Hanke Mollnau, Rudolf Strasser, Robert Wenz, Wulf Ito, Jutta Schaper, Wolfgang Schaper. 1998. The delivery of angiogenic factors to the heart by microsphere therapy. Nature Biotechnology 16:2, 159-162. [CrossRef]

37. Suezanne E. Parker, Sylvie Ducharme, Jon Norman, Carl J. Wheeler. 1997. Tissue Distribution of the Cytofectin Component of a Plasmid-DNA/Cationic Lipid Complex Following Intravenous Administration in MiceTissue Distribution of the Cytofectin Component of a Plasmid-DNA/Cationic Lipid Complex Following Intravenous Administration in Mice. Human Gene Therapy 8:4, 393-401. [Abstract] [PDF] [PDF Plus]

38. Margreet A. Wolfert, Etienne H. Schacht, Veska Toncheva, Karel Ulbrich, Ola Nazarova, Leonard W. Seymour. 1996. Characterization of Vectors for Gene Therapy Formed by Self-Assembly of DNA with Synthetic Block Co-PolymersCharacterization of Vectors for Gene Therapy Formed by Self-Assembly of DNA with Synthetic Block Co-Polymers. Human Gene Therapy 7:17, 2123-2133. [Abstract] [PDF] [PDF Plus]

39. Dominique J. Stephan, Zhi-Yong Yang, Hong San, Robert D. Simari, Carl J. Wheeler, Philip L. Felgner, David Gordon, Gary J. Nabel, Elizabeth G. Nabel. 1996. A New Cationic Liposome DNA Complex Enhances the Efficiency of Arterial Gene Transfer In VivoA New Cationic Liposome DNA Complex Enhances the Efficiency of Arterial Gene Transfer In Vivo. Human Gene Therapy 7:15, 1803-1812. [Abstract] [PDF] [PDF Plus]

40. Jukka Hartikka, Michael Sawdey, Francine Cornefert-Jensen, Michal Margalith, Kerry Barnhart, Michelle Nolasco, H. Lee Vahlsing, Jennifer Meek, Magda Marquet, Peter Hobart, Jon Norman, Marston Manthorpe. 1996. An Improved Plasmid DNA Expression Vector for Direct Injection into Skeletal MuscleAn Improved Plasmid DNA Expression Vector for Direct Injection into Skeletal Muscle. Human Gene Therapy 7:10, 1205-1217. [Abstract] [PDF] [PDF Plus]

41. Suezanne E. Parker, H. Lee Vahlsing, Laurie M. Serfilippi, Craig L. Franklin, Soeun G. Doh, Stanislaw H. Gromkowski, Denise Lew, Marston Manthorpe, Jon Norman. 1995. Cancer Gene Therapy Using Plasmid DNA: Safety Evaluation in Rodents and Non-Human PrimatesCancer Gene Therapy Using Plasmid DNA: Safety Evaluation in Rodents and Non-Human Primates. Human Gene Therapy 6:5, 575-590. [Abstract] [PDF] [PDF Plus] 